NBER WORKING PAPER SERIES

\title{
IS THE U.S. CURRENT ACCOUNT DEFICIT SUSTAINABLE? AND IF NOT, HOW COSTLY IS ADJUSTMENT LIKELY TO BE?
}

\author{
Sebastian Edwards \\ Working Paper 11541 \\ http://www.nber.org/papers/w11541
NATIONAL BUREAU OF ECONOMIC RESEARCH 1050 Massachusetts Avenue
Cambridge, MA 02138
August 2005

This is a revised version of a paper presented at the Spring 2005 meeting of the Brookings Panel on Economic Activity. I thank Ed Leamer for helpful discussions, and Roberto Alvarez for his assistance. I am grateful to the editors and to my discussants Katharine Dominguez and Pierre-Olivier Gorinchas for their comments. The views expressed herein are those of the author(s) and do not necessarily reflect the views of the National Bureau of Economic Research.

(O2005 by Sebastian Edwards. All rights reserved. Short sections of text, not to exceed two paragraphs, may be quoted without explicit permission provided that full credit, including $\odot$ notice, is given to the source. 
Is the U.S. Current Account Deficit Sustainable? And If Not, How Costly is Adjustment Likely

To Be?

Sebastian Edwards

NBER Working Paper No. 11541

August 2005

JEL No. F02, F43, O11

\title{
ABSTRACT
}

In this paper I analyze the relationship between the U.S. dollar and the U.S. current account. I deal with issues of sustainability, and I discuss the mechanics of current account adjustment. The analysis presented in this paper differs from other work in several respects: First, I emphasis the dynamics of the current account adjustment, going beyond computations of the "required" real depreciation of the dollar to achieve sustainability. I show that even if foreigners' (net) demand for U.S. assets continues to increase significantly, the current account deficit is likely to experience a large decline in the (not too distant) future. Second, I rely on international evidence to explore the likelihood of an abrupt decline in capital flows into the U.S. And third, I analyze the international evidence on current account reversals, to investigate the potential consequences of a (possible) sudden stop of capital flows into the U.S. This analysis suggests that the future adjustment of the U.S. external accounts is likely to result in a significant reduction in growth.

\author{
Sebastian Edwards \\ UCLA Anderson Graduate School of Business \\ 110 Westwood Plaza, Suite C508 \\ Box 951481 \\ Los Angeles, CA 90095-1481 \\ and NBER \\ sebastian.edwards@anderson.ucla.edu
}




\section{Introduction}

During the last few years a large number of analysts in academia, the private sector and applied research institutions have expressed increasing concerns regarding the growing U.S. current account deficit. There is a generalized sense that the current situation of global imbalances is unsustainable and that adjustment will have to take place sooner rather than later. The unprecedented magnitude of the U.S. current account deficit and the growing net indebtedness of the U.S. have fueled analysts' worries, with many arguing that unless something is done, the world will move toward a major financial crisis. ${ }^{1}$ Some authors have gone as far as suggesting an imminent collapse of the U.S. dollar, and a global financial meltdown. ${ }^{2}$ The main idea behind this view is that if the U.S. current account deficit is maintained at its current level, U.S. net international liabilities will reach $100 \%$ of GDP, a figure considered to be excessively large. ${ }^{3}$ In a recent paper, Mussa (2004) has said:

"[T]here is probably a practical upper limit for the US net external liabilities at something less than 100 percent of US GDP and, accordingly...current account deficits of 5 percent or more of US GDP are not indefinitely sustainable." (Mussa 2004, p 114).

The source of financing of the U.S. current account deficit has also become a source of concern. A number of authors have argued that by relying on foreign -- and particularly Asian -- central banks' purchases of Treasury securities, the U.S. has become particularly vulnerable to sudden changes in expectations and economic sentiments. ${ }^{4}$

Robert Skidelsky has recently argued in The New York Times that the value of the dollar is one of the most important sources of political tension between the United States and Europe. According to him, "[U]nilateralism is not more acceptable in currency matters than in foreign policy." More specifically, Skidelsky has pointed out that,

\footnotetext{
1 Although most of the alarmist discussions have come in the form of Op-Ed pieces, there have also been a few policy papers on the subject. See, for example, Roubini and Setser (2004).

2 See, for example, Roubini and Setser (2004). For an excellent set of papers on the subject see Bergsten and Williamson (2004).

3 See Mussa (2004) for a very clear discussion of this issue.

${ }^{4}$ See, for example, Martin Wolf's October $1^{\text {st }}, 2003$ article in the Financial Times, "Funding America's recovery is a very dangerous game," (page 15).
} 
"The United States is the only major country proclaiming itself indifferent to its currency value. In countries running persistent current account deficits, governments normally -- indeed must - reduce domestic consumption. But so far, the United States has relied on other countries to adjust their economies to profligate American spending... (The New York Times, February $20^{\text {th }}, 2005$, p.9)

There is, however, an alternative view. Some authors have argued that in an era of increasing financial globalization and rapid U.S. productivity gains, it is possible even logical and desirable -- for the U.S. to run (very) large current account deficits for a very long period of time (say, a quarter of a century). According to this view, growing international portfolio diversification implies that the "rest of the world" will be willing to accumulate large U.S. liabilities during the next few years; maybe even in excess of $100 \%$ of U.S. GDP. According to this perspective, since the U.S. current account deficit does not pose a threat, there are no fundamental reasons to justify a significant fall in the value of the U.S. dollar (Dooley, Folkerts-Landau and Garber 2004a, 2004b). ${ }^{5}$

The purpose of this paper is to analyze the relationship between the U.S. dollar and the U.S. current account. In particular, I deal with issues of sustainability and I discuss the mechanics of current account adjustment. I develop a portfolio model of the current account and I show that even under a very positive scenario, where foreigners' (net) demand for U.S. assets doubles relative to its current level, the U.S. current account will have to go through a significant adjustment in the (not too distant) future. Indeed, it is not possible to rule out a scenario where the U.S. current account deficit would shrink abruptly by 3 to 6 percent of GDP. In order to have an idea of the possible consequences of this type of adjustment, I analyze the international evidence on current account reversals. The results from this empirical investigation indicate that significant current account reversals have tended to result in large declines in GDP growth.

The rest of the paper is organized as follows: In section II I provide some background information and data. I discuss the evolution of the U.S. real exchange rate (RER) and current account during the last three decades, and I analyze some of the statistical properties of the RER. I discuss the sources of deficit financing and I analyze

\footnotetext{
${ }^{5}$ See, also, Cooper (2004), and Caballero, Farhi and Hammour (2004).
} 
the evolution of the U.S. net international assets position. In this section I also provide international comparisons, and I put the current U.S. situation in a global comparative context. In Section III I deal with the analytics of current account and real exchange rate adjustment. The analysis presented in this section focuses on transitional dynamics, and goes beyond computations of the "required" real depreciation of the dollar to achieve current account sustainability. I develop a portfolio model of current account behavior, and I discuss the response of the current account to changes in international portfolio choices. The model is quite general and allows for valuation effects stemming from exchange rate changes, and for changes in the international terms of trade. I show that under plausible parameters, an increase in the demand for U.S. assets by foreign investors results in an "overshooting" of the current account deficit. According to the model the current account deficit will increase until, at some point, it will experience a reversal. The reversal may, indeed, be quite abrupt and significant. In Section IV I use a large cross-country data set to investigate the international evidence on current account reversals. In particular, I investigate whether countries that have experienced significant and rapid reversals have faced real costs in the form of a decline in the rate of GDP growth. I argue that in spite of the uniqueness of the U.S., as a large country whose currency is at the center of the global financial system, this comparative analysis provides useful information on the likely costs an eventual U.S. current account adjustment. The paper closes with Section V, where I discuss some global policy challenges and I offer some concluding remarks.

\section{The U.S. Dollar and the Current Account: A Thirty Years Perspective}

In this section I analyze the evolution of the U.S. real exchange rate and current account since the adoption of floating exchange rates in the early 1970s. The section is divided in three parts: ${ }^{6}$ First, I discuss the evolution of the U.S. real exchange rate (RER) and current account during the last three decades, and I deal with the changing

\footnotetext{
6 Due to space considerations I have not discussed in detail some important issues, such as the stationarity of the RER and its (changing) volatility through time. Most recent analyses based on panel data have found that the RER is stationary and that its half-life cycle is lower than the 3 to 5 years traditionally considered as the "consensus view." See Choi, Mark and Sul (2005). An analysis of U.S. RER volatility indicates that for the complete period (1975-2004) the U.S. real exchange rate index exhibited one of the highest volatilities in the sample. Only the British pound, the Japanese yen, and the euro have higher volatilities. Second, RER volatility for the U.S. dollar was highest in 1985-1989. This period corresponds, mostly, to the rapidly depreciating Phase III in Figure 2.
} 
nature of the U.S. trade-weighted RER index. I argue that it is possible to divide the last thirty years of RER behavior into six distinct phases. Second, I discuss the most recent data on the U.S. current account, including its sources of financing. And third, I provide some international evidence on current account imbalances during the last three decades. This comparative analysis allows to place the U.S. recent experience in a historical context.

\section{II.1 Six Phases of Real Exchange Rate Behavior}

In Figure 1 I present quarterly data for the U.S. current account balance as percentage of GDP, as well as on the evolution of the Federal Reserve trade-weighted index of the U.S. dollar real exchange rate for the period 1973-2004; in this Figure - as in the rest of this paper --, an increase in the RER index represents a real exchange rate appreciation. Several interesting features emerge from Figure 1: First, it shows that deficits have become increasingly large since 1992. Second, Figure 1 shows that for the first decade of floating exchange rates (1973-1982), the US ran, on average, a small current account surplus of $0.04 \%$ of GDP. In contrast, for the period 1983-2004 the average current account balance has been a deficit of $2.4 \%$ of GDP. Figure 1 also shows that during the period under consideration the RER index experienced significant movements: its mean was 105.3, its minimum 91.2, and its maximum was 136.3. Finally, Figure 1 shows a pattern of negative correlation between the trade-weighted real value of the dollar and the current account balance. Periods of strong dollar have tended to coincide with periods of (larger) current account deficits. Although the relation is not one-to-one, the degree of synchronicity between the two variables is quite high: the contemporaneous coefficient of correlation between the (log of the) RER index and the current account balance is -0.53 ; the highest correlation of coefficient is obtained when the log of the RER is lagged three quarters (-0.60).

Recent policy debates on the value of the U.S. dollar illustrate the massive changes that have occurred in U.S. trade relations during the last three decades. While in the early 1970's dollar-related discussions dealt almost exclusively with bilateral exchange rates - both nominal and real -- with respect to the industrial countries, more recent debates have increasingly focused on the behavior of emerging countries' currencies, including the Chinese renminbi, the Korean won, and the Malaysian ringgit. 
During the last few years the Mexican peso has also become an important currency in determining the trade-weighted value of the U.S. dollar; this was not the case in 1973, when the Smithsonian Agreement was abandoned. Between 1995 and 2005 China's weight in the Federal Reserve trade-weighted real exchange rate index has gone from $5.67 \%$ to $11.35 \%$; Mexico's weight has increased from $6.95 \%$ to $10.04 \%$. On the other hand, during the same period, Japan's weight has declined from $16.54 \%$ to $10.58 \%$. Overall, today's trade-weighted U.S. RER is dominated by the Asian nations - as a group, the Asian countries (excluding India) have a weight in the index of $38.8 \%$. Commodity currencies, as a group, are also very important, with a weight of $24.6 \%$. Finally, the launching of the Euro in 1999 has marginalized the British pound. Although a weight of 5.2\% is still quite "respectable," the pound is not any longer among the top 5 currencies in the index. The situation was quite different in 1998, when the weight of the British pound was higher than that of all, but one, of the currencies that eventually would conform the euro (in 1998 the German mark had a weight of $6.4 \%$ and the British pound had a weight of $5.9 \%)^{7}$

As may be seen from Figure 1, it is possible to distinguish six distinct phases in U.S. dollar real exchange rate behavior for the thirty-year period 1975-2004. A brief analysis of these six phases provides a summary of the history of the international financial system since the inception of floating: ${ }^{8}$

- Phase I: 1973Q1-1978Q4. This period includes the early years of floating, and was characterized by a depreciating trend of the U.S. RER. The accumulated depreciation amounted to $18.1 \%$ during 24 quarters. During this period the standard deviation of the monthly log differences of the RER index was 0.0205. During the early part of this phase (1973-76) the current account was in surplus. This, however, turned into a small deficit in the years 1977 and 1978.

- Phase II: 1979Q1-1985Q1. During these 26 quarters the U.S. dollar RER experienced a $49.3 \%$ appreciation. During this phase the current account

\footnotetext{
7 In 2005 the euro has a weight of $18.80 \%$; in 1995 the currencies that conformed the euro had a combined weight of $17.30 \%$.

8 Figure 1 presents the Fed broad RER index. The same six phases are observed if alternative indexes are used.
} 
went into deficit, reaching $2.9 \%$ of GDP in the third quarter of 1984 . The standard deviation of the monthly log differences of the RER index was 0.022, slightly higher than that of Phase I. In view of the substantial strengthening of the dollar and the related increase in the U.S. current account deficit, on September $25^{\text {th }} 1985$ the members of the G-5 (The United Sates, Japan, the United Kingdom, France, and Germany) decided to implement concerted and coordinated interventions in the foreign exchange market. As part of this agreement - known as the Plaza Accord - the G-5 countries committed themselves to put in place coordinated macroeconomic policies that would reduce the costs of the global adjustment process. ${ }^{9}$

- Phase III: 1985Q2-1988Q4. During this period the dollar real exchange rate experienced a rapidly depreciating trend. The peak-to-trough change in the index was $-28.7 \%$. Real exchange rate volatility increased substantially during this 16 quarter period; the standard deviation of the monthly log differences of the RER index was 0.0268, substantially higher than in the previous two phases. The current account deficit continued to grow, until in mid 1987 it stabilized at around 3.6\% of GDP. From that point onward the current account began to improve, and by the fourth quarter of 1988 the deficit had declined to $2.4 \%$ of GDP. On February 22, 1987 the Ministers of Finance and Central Bank Governors of the G-6 (G-5 plus Canada) released a communiqué - known as the Louvre Accord -- informing the public that significant progress had been made in achieving global adjustment, and that "further substantial exchange rate shifts among their currencies could damage growth and adjustment prospects in their countries..." The Louvre Accord communiqué went on to say that the G-6 countries "agreed to cooperate closely to foster stability of exchange rates around current levels."10

- Phase IV: 1989Q1-1995Q2. During this Phase the real value of the dollar continued to depreciate, but at a much lower rate than in the preceding Phase; during these 27 quarters the dollar depreciated in real terms by $10 \%$. During

9 For the text of the Plaza Accord communiqué, see http://www.g8.utoronto.ca/finance/fm850922.htm.

10 See the text of the Louvre Accord at http://www.g8.utoronto.ca/finance/fm870222.htm. 
this period the standard deviation of the monthly log differences of the RER index was 0.0232. During this phase the current account balance continued to improve, until in the first quarter of 1991 the U.S. posted its first current account surplus in many years. During Phase IV the average current account balance was $-1.15 \%$ of GDP.

- Phase V: 1995Q3-2002Q1. This is phase is characterized by a trough-topeak real exchange rate appreciation of $33.4 \%$ (notice from Figure 1 that between the fourth quarter of 1998 and the fourth quarter of 1999 there was a short lived period of real depreciation). Interestingly, during this phase real exchange rate volatility declined significantly; the standard deviation of the monthly log differences of the RER index was 0.0196. This phase was characterized by an increasingly larger current account deficit. While in late 1995 early 1996 the deficit was in the order of $1.5 \%$ of GDP, by early 2002 it was hovering just below 4\% of GDP. In 1999, and for the first time in many years, the U.S. federal government posted a surplus.

- Phase VI: 2002Q2-2004Q4. This phase is continuing at the time of this writing. Between the second quarter of 2002 and the fourth quarter of 2004 the real value of the dollar experienced a $14 \%$ accumulated depreciation. The current account deficit continued to widen, exceeding 5\% of GDP towards the end of the sample. Real exchange rate volatility increased slightly during this period; the standard deviation of the log differences of the RER index was 0.0212. Other important macroeconomic developments during this phase include the worsening of the U.S. fiscal position, and the stiff increases in the price of oil and other commodities.

In Figure 2 I go beyond the current account, and I present data from 1973 through 2004 for: (a) the balance of trade of goods and services as a percentage of GDP; (c) the balance of trade in (non financial) services as a percentage of GDP; (c) the income account, also as a percentage of GDP and (d) the transfers account as a percentage of GDP. A number of important facts emerge from these figures. First, as Panel A shows, large and persistent trade deficits have preceded in time the era of large current account 
deficits. Already in the late 1970s the trade account was negative, and since mid 1976 it has had only one surplus quarter (1992Q2). ${ }^{11}$ Second, since 1996 the trade surplus in non financial services has declined steadily; in 2004 it was only 0.3 percent of GDP. Third, Panel $\mathrm{C}$ shows that the income account continues to be positive. Since for quite some years now the U.S. international investment position has been negative - that is, the U.S. has been a net debtor --, the fact that the income account is still positive may seem surprising. The reason for this is that the return on U.S. assets held by foreigners has been systematically lower than the return on foreign assets in hands of U.S. nationals. Finally, Panel D shows that the transfers account has been negative since 1946. During the last few years transfers account deficit has been stable at approximately $0.7 \%$ of GDP.

\section{II.2 Recent Current Account Imbalances}

In Table 1 I present data on the current account as a percentage of GDP, and its financing for the period 1990-2004. As may be seen, during the last few years the nature of external financing has changed significantly. In particular, since 2002 net FDI flows have been negative. This contrasts with the 1997-2001 period when FDI flow contributed in an increasingly important way to deficit financing. Also, after four years on net positive equity flows (1998-2002), these became negative in 2003-04. As the figures in Table 1 show, during 2003 and 2004 the U.S. current account deficit was fully financed through net fixed income flows. Official foreign purchases of government securities (Reserves (net), in Table 1) have played a particularly important role in the financing of the 2003 and 2004 current account deficits. A number of analysts have argued that by relying on foreign central banks' purchases of Treasury securities, the U.S. has become particularly vulnerable to sudden changes in expectations and economic sentiments. $^{12}$

Current account imbalances are reflected in changes in a country's net international investment position (NIIP): deficits result in a deterioration of the NIIP, and surpluses result in an improvement in the U.S. NIIP. In Figure 3 I present the evolution

\footnotetext{
11 Mann (2004) shows that most of the U.S. trade deficit is explained by a deficit in automobiles and consumer goods.

${ }^{12}$ See, for example, Martin Wolf's October $1^{\text {st }}, 2003$ article in the Financial Times, "Funding America's recovery is a very dangerous game," (page 15).
} 
of the U.S. NIIP as percentage of GDP. As may be seen, this has become increasingly negative: in 2004 U.S. net international liabilities reached 29 percent of GDP. An important feature of the NIIP is that gross U.S. international assets and gross U.S. international liabilities are held in different currencies. While more than $70 \%$ of gross foreign assets held by U.S. nationals are denominated in foreign currency, approximately 95\% of gross U.S. liabilities in hands of foreigners are denominated in U.S. dollars. This means that the net liabilities as a percentage of GDP are subject to "valuation effects" stemming from changes in the value of the dollar. A dollar depreciation reduces the value of net liabilities. As a result of this valuation effect, the deterioration of the U.S. NIIP during 2002-2004 was significantly smaller than the accumulated current account deficit during those two years; see Table 2 for details.

A key question in current account sustainability analyses - and one I discuss in detail below - refers to the "reasonable" long run equilibrium value the ratio of U.S. net international liabilities; the higher this ratio is, the higher will be the "sustainable" current account deficit. According to some authors the current ratio of almost $30 \%$ of GDP is excessive, while others believe that a NIIP to GDP ratio of up to $50 \%$ would be reasonable. ${ }^{13}$

One of the first things undergraduate students of open economy macroeconomics learn is that the current account is the difference between savings and investment. Through time a number of authors have argued that a worsening of a current account balance that stems from an increase in investment is very different from one that results from a decline in national savings. Some have gone as far as arguing that very large deficits in the current account "don't matter," as long as they are the result of higher (private sector) investment (Corden, 1994). As Figure 4 shows, the recent deterioration of the U.S. current account has largely been the result of a decline in national savings, and in particular of public and household savings. A simple implication of this trendand one that is emphasized by most authors - is that an improvement in the U.S. current account situation will not only imply a RER adjustment; it will also require an increase in the national savings ratio, and in particular in household savings. Symmetrically, a

13 See Obstfeld and Rogoff (2004) and Mussa (2004). 
correction of current global imbalances will also require a decline in Europe's and Japan's savings rates and/or an increase in their investment rates.

\section{II.3 The U.S. Current Account Deficit in International Perspective}

How large is the U.S. recent current account deficits, from a comparative point of view? And, how large is the U.S. net international liabilities position when compared, from a historical vantage, to that of other advanced countries? In Table 3 I present data on the distribution of current account balances in the world economy, as well as in six groups of nations - Industrial, Latin America, Asia, Middle East, Africa and Eastern Europe - for the period 1971-2001. As may be seen, at almost 6\% of GDP the U.S. deficit is very large from a historical and comparative perspective. It is in the top decile of deficits distribution for all industrial countries in the first thirty years of floating. As the data in Table 3 suggest the U.S. looks more like a Latin American or Asian country, than like an industrial nation.

Since 1971 the U.S. has been the only large industrial country that has run current account deficits in excess of 5\%. This reflects the unique position that the U.S. has in the international financial system, where its assets have been in high demand, allowing it to run high and persistent deficits. On the other hand, this fact also suggests that the U.S. is moving into uncharted waters. As Obstfeld and Rogoff (2004), among others, have pointed out, if the deficit continues at its current level, in twenty five years the U.S. net international liabilities will surpass the levels observed by any country in modern times.

During the last 30 years only small industrial countries have had current account deficits in excess of 5\% of GDP: Australia, Austria, Denmark, Finland, Greece, Iceland, Ireland, Malta, New Zealand, Norway and Portugal. What is even more striking is that very few countries - either industrial or emerging -- have had high current account deficits that last for more than five years. In Table 4 I present a list of countries with persistently high current account deficits for 1970-2001. In constructing this table I define a country as having a "High Deficit" if, in a particular year, its current account deficit is higher than its region's ninth decile. ${ }^{14}$ I then defined a persistently high deficit country, as a country with a "High Deficit" (as defined above) for at least 5 consecutive

\footnotetext{
14 Notice that the thresholds for defining High deficits are year and region-specific. That is, for every year there is a different threshold for each region.
} 
years. ${ }^{15}$ As may be seen in Table 4 the list of persistently high deficit countries is extremely short, and none of these countries is large. This illustrates the fact that, historically, periods of high current account imbalances have tended to be short lived, and have been followed by periods of current account adjustments.

In Table 5 I present data on net international liabilities as a percentage of GDP for a group of advanced countries that have historically had a large negative NIIP position. ${ }^{16}$ As may be seen, the picture that emerges from this table is different than that in Table 4 on current account deficits. Indeed, a number of advanced nations have had - and continue to have - a significantly larger net international liabilities position than the U.S. This suggests that, at least in principle, the U.S. NIIP could continue to deteriorate for some time into the future. But even if this does happen, at some point this process would have to come to an end, and the U.S. net international liabilities position as percentage of GDP would have to stabilize. It makes a big difference, however, at what level U.S. net international liabilities do stabilize. For example, if in the steady state foreigners are willing to hold the equivalent of $35 \%$ of U.S. GDP in the form of net U.S. assets, the U.S. could sustain a current account deficit of (only) $2.1 \%$ of GDP. ${ }^{17}$ If, on the other hand, foreigners' net demand for U.S. assets grows to 60\% of GDP - which, as shown in Table 5, is approximately the level of (net) foreign holdings of Australian assets --, the U.S. sustainable current account deficit is 3.6\% of GDP. And if foreigners' are willing to hold (net) U.S. assets for the equivalent of $100 \%$ of GDP - a figure that Mussa (2004) considers to be implausible - the sustainable U.S. current account deficit can be as high as $6 \%$ of GDP - approximately its current level.

Since there are no historical precedents for a large advanced nation running persistently large deficits, it is extremely difficult to have a clear idea on what will be the actual evolution of foreigners' demand for U.S. assets. Give this lack of historical precedent, a reasonable strategy is to ask what would happen to the current account and

\footnotetext{
15 For an econometric analysis of current account deficits persistence see Edwards (2004). See also Taylor (2002).

16 For the U.S. the data are from the Bureau of Economic Analysis. For the other countries the data are, until 1997, from the Lane and Milessi-Ferreti data set. I have updated them using current account balance data. Notice that the updated figures should be interpreted with a grain of salt, as I have not corrected them for valuation effects.

17 This calculation assumes a $6 \%$ rate of growth of nominal GDP going forward. See subsection III for an analytical discussion and for the relevant equations.
} 
real exchange rate dynamics if, as posited by Dooley et al (2004a) among others, foreigners' demand for U.S. assets continues to increase. This is precisely approached I follow in Section III of this paper.

\section{The Analytics of Current Account and Real Exchange Rate Adjustment}

The current account and the (real) exchange rate are endogenous variables jointly determined in a general equilibrium context. This means that from a policy point of view the key question is how will these two variables move as a result of a given exogenous shock - a decline in capital inflows, say --, under the assumption that other variables, including growth and the rate of unemployment, do not deviate significantly from their long term equilibrium paths. A number of authors have recently addressed this issue using a variety of simulation and econometric models. Most of these studies have asked what is the real exchange rate adjustment "required" to achieve a certain current account balance. Some authors, such as Obstfeld and Rogoff (2000, 2004) and Blanchard, Giavazzi and $\mathrm{Sa}$ (2005), have considered the case where the deficit is competently eliminated. Others, including Mussa (2004) and Roubini and Setser (2004), have considered the reduction of the deficit to a positive, but smaller than current, level. In Table 6 I provide a summary of selected studies on the subject. As may be seen, these works use different methodologies, and reach different conclusions. ${ }^{18}$ What they do have in common, however, is that they find "required" adjustments in the trade-weighted value of the U.S. dollar is quite high - according to Blanchard, Giavazzi and Sa (2005) as high as $90 \%$. Interestingly, the estimated figures for "required" dollar depreciation summarized in Table 6 are much higher than the figures discussed in most investment banks' newsletters and in the media. ${ }^{19}$

\section{III.1 A Portfolio Model of the Current Account and the Real Exchange Rate}

From an analytical perspective the process of current account adjustment may be deconstructed into two components: (a) The dynamics of net international foreign assets; and (b) the "transfer" associated with changes in a country's net foreign assets position.

18 See also the studies by Mann $(2003,2004)$, where she extends her pioneering 1999 model.

19 While practitioners' do believe that the dollar will weaken, they tend to consider more moderate adjustments. See, for example, the forex publications of major investment banks. 
Changes in international investors' willingness to hold U.S. assets will affect total absorption and relative prices, including the real exchange rate. An increase in foreigner's rate of accumulation of domestic assets will allow the country to increase absorption, generating a current account deficit and a RER appreciation. In a similar way, a reduction in the rate at which foreigners accumulate the country's assets - or, worse yet, a reduction in their holdings of domestic assets -- will result in a drop in absorption and a decline in the relative price of nontradables, or RER depreciation. These changes in absorption, and the concomitant adjustment in relative prices, are reminiscent of discussions on the "transfer problem" that go back, at least, to the debates between Keynes and Ohlin during the 1920s. In large countries such as the U.S., however, this story is more complex. First, changes in relative prices have valuation effects on net foreign assets holdings that will feed back into the dynamics of net foreign assets accumulation or de-accumulation. ${ }^{20}$ Second, in a large country changes in aggregate expenditure are likely to affect the international terms of trade, and thus the general equilibrium outcome of the original shock.

\section{III.1.1 The Basic Model}

Consider the following bare bones portfolio model of the current account: ${ }^{21}$ Equation (1) is the basic external sector equation (in domestic currency) and states that the current account deficit $(C A D)$ is equal to the trade deficit $(T D)$, plus the income account (net income payments to the rest of the world) $\left(i a_{t}\right)$, plus net transfers to the rest of the world $(N T) .^{22}$

$$
C A D_{t}=T D_{t}+i a_{t}+N T_{t}
$$

The income account, in turn is equal to:

$$
i a_{t}=i D_{t}^{f}-i^{*} F_{t}^{d}
$$

20 This effect has been emphasized by Lane and Milessi-Ferreti (2002, 2004a, 2004b), Tille (2003) and Gourinchas and Rey (2005), among others. For a discussion of valuation effects in the context of emerging markets' current account sustainability, see Edwards (2003).

21 In order to concentrate on the problem at hand and to keep the analysis tractable, I have made a number of simplifications; I have made no attempt to construct a full general equilibrium model. Recent papers that have constructed portfolio models of the current account include, Blanchard, Giavazzi and Sa (2005), Edwards (1999, 2002), Gourinchas and Rey (2005) and Kraay and Ventura (2002).

${ }^{22}$ Notice that I have defined the deficit as a positive number. In equation (1), then, negative numbers refer to a surplus. 
where $i$ is the interest rate paid on (gross) domestic assets in hand of foreigners $D_{t}^{f}$, and $i^{*}$ is the interest rate on (gross) foreign assets held by domestic residents $F_{t}{ }^{d}$. Since equation (1) is expressed in domestic currency,

$$
F_{t}^{d}=E_{t} F_{t}^{d^{*}} .
$$

Where $E$ is the nominal exchange rate defined as units of domestic currency (U.S. dollars) per unit of foreign currency, and $F_{t}^{d^{*}}$ denotes (gross) foreign assets held by domestic residents, expressed in foreign currency. Equation (1) can then be rewritten as follows:

$$
C A D_{t}=T D_{t}+i \delta_{t}+\left(i-i^{*}\right) F^{d}+N T_{t} .
$$

Where $\delta$ are net domestic assets in hands of foreigners $\left(\delta_{t}=D^{f}-F^{d}\right)$. The terms $i \delta_{t}$ and $\left(i-i^{*}\right) F^{d}$ capture the effect of valuation effects on the current account, recently emphasized by a number of authors including Lane and Milesi-Ferreti (2004), and Gourinchas and Rey (2005), among others.

Equation (2) is a portfolio equation that summarizes the net international demand for the country's assets $\delta_{t}$. Domestic and foreign assets are assumed to be imperfect substitutes. $\alpha$ is the percentage of foreigners' wealth that international investors are willing to hold in the form of the domestic country's assets; $W$ is world's wealth and $W^{c}$ is the domestic country's wealth. $\alpha_{i j}$ is the domestic country's asset allocation on its own assets. I assume that there is "home-bias" in portfolio decisions; this is reflected in the fact that $\alpha_{j}$ and $\left(1-\alpha_{j j}\right)$ are below international market shares of domestic and foreign wealth. There is no need, however, to assume that foreign and domestic investors have the same degree of home bias.

$$
\delta_{t}=\alpha\left(W_{t}-W_{t}^{c}\right)-\left(1-\alpha_{j j}\right) W_{t}^{c},
$$

An important question is what determines the asset allocation shares $\alpha$ and $\alpha_{j j}$. Under standard portfolio theory, $\alpha$ and $\alpha_{j j}$ will depend on expected real returns ( $i$ and $\left.i^{*}\right)$, 
perceived risk $\left(\mu, \mu^{*}\right)$, and the degree of segmentation of international financial markets (Equation (3)).

$$
\alpha=\alpha(i, \mu) ; \alpha_{j j}=\alpha_{j j}\left(i^{*}, \mu^{*}\right) .
$$

In this paper, however, I make the simplifying assumption that foreign and domestic assets have zero substitutability. This is equivalent to assuming that $\alpha$ and $\alpha_{j j}$ are exogenously determined, and not affected by $i$ or $i^{*}$. This assumption allows me to focus on the effects of exogenous changes in portfolio allocation on net assets dynamics and the current account. However, in subsection III.2.2 I discuss the way in which the results will be altered if some degree of substitutability between domestic and foreign assets is allowed.

World wealth in foreign currency $W^{*}$ and in domestic currency $W$ are related by $W_{t}^{*}=\frac{W_{t}}{E_{t}}$. Domestic and foreign interest rates are related through the following equation: $i=i^{*}+\frac{d E^{e}}{E}+\left(\mu-\mu^{*}\right)+k$, where $\frac{d E^{e}}{E}$ is the expected rate of depreciation of the domestic currency, and $k$ is a term that captures the effect of capital controls; in a world of full capital mobility, $k=0$. It is important to notice that in this model the term "investors" refers both to private and public investors, and include foreign central banks. Indeed, and as pointed out in the preceding section, recent discussions on the U.S. current account deficit have emphasized the key role played by foreign (and especially Asian) central banks in helping finance the deficit.

The counterpart of a current account deficit $C A D$ is the change in the country's (net) assets in hand of foreigners:

$$
C A D_{t}=\Delta \delta_{t} .
$$

Equation (5) defines the trade deficit.

$$
T D_{t}=\sum p_{i}^{m} m_{i}-\sum p_{i}^{x} x_{i}
$$

$p_{i}^{m}$ and $p_{i}^{x}$ are prices of importable and exportables in domestic currency. $m_{i}$ is the demand for importables, which is assumed to depend on the real exchange rate $(e)$, the international price of importable goods, the country's real income $(y)$, and other factors, 
including the degree of protectionism (v). Exports, on the other hand, depend on the real exchange rate, the international price of exportables, the rest of the world real income $\left(y^{*}\right)$ and other factors $(u)$.

$$
m_{i}=m_{i}(e, y, v) ; \quad x_{i}=x_{i}\left(e, y^{*}, u\right) .
$$

$m_{i}$ and $x_{i}$, in turn, may be interpreted as excess demand (supply) for importable (exportables), in the domestic country. In the basic version of the model it is assumed that the law of one price holds for importables and exportables: $p_{i}^{m}=E p_{i}^{m^{*}} ; p_{i}^{x}=E p_{i}^{x^{*}}$. In the simulation exercises alternative assumptions can be made, however, including that exporters and importers price to market. Equation (7) is the equilibrium condition for the nontradable goods market in the home country, where $S_{t}^{N}$ is the supply of nontradables in period $\mathrm{t}$, assumed to depend on the real exchange rate and other factors $\mathrm{z}$, and $D_{t}^{N}$ is the demand for nontradables:

$$
S_{t}^{N}\left(e_{t}, z_{t}\right)=D_{t}^{N}\left(e_{t}, y_{t}\right) .
$$

The domestic price level $P$ is assumed to be a geometric average of the nominal prices of tradable goods (importables and exportables) and nontradables:

$P_{t}=\left(p_{t}^{m}\right)^{a}\left(p_{t}^{x}\right)^{b}\left(p_{t}^{N}\right)^{(1-a-b)}$. Equation (8) is the real exchange rate.

$$
e_{t}=\frac{P_{t}}{E_{t} P_{t}^{*}},
$$

where, $P_{t}^{*}$ is the foreign country price level. As before, an increase in $e$ represents a real appreciation; a decrease in $e$ is a real depreciation.

The working of this model is simple. The domestic country can only run a current account deficit to the extent that foreign investors are willing to increase their net holdings of domestic assets - that is, to the extent that $\Delta \delta_{t}>0$. Once $\Delta \delta_{t}$ is known, and for given values of other key variables, it is possible to derive the real exchange rate $(e)$ consistent with the prevailing current account deficit (surplus). A particularly interesting exercise, given the current U.S. situation, is to analyze how changes in portfolio preferences - that is, changes in $\alpha$ and/or $\alpha_{j j}{ }^{--}$, will affect the current account and the real exchange rate. 
In order to close the model, it is necessary to specify a number of clearing conditions, including the savings and investment equations in the world economy; and the world clearing conditions for each importable and exportable good. These equilibrium conditions determine endogenously interest rates, and all relevant tradable goods' prices. Doing this, however, would make the model significantly more complex than what is required for dealing with the problem at hand. For this reason, instead of solving the full model, I work with a partial equilibrium version of it; in the simulations that follow I make different assumptions regarding these variables' behavior. ${ }^{23}$

Before continuing, however, it is important to emphasize that current account adjustments will not only imply changes in the real exchange rate; they will also require changes in savings and investments in the home country (the U.S.) and the rest of the world. From a policy perspective these adjustments in domestic savings would be greatly facilitated by an increase in public sector savings.

\section{III.1.2 Portfolio Equilibrium, Dynamics and Current Account Sustainability}

External sustainability requires that a country's net external liabilities stabilize at a level compatible with foreigners' net demand for these claims, as specified by equation (2). Assuming that the home country's wealth is a multiple $\lambda$ of its (potential or full employment) GDP, and that its wealth is a fraction $\beta$ of world's wealth $W$, it is possible to rewrite the (international) net demand for the country's assets as $\delta=\left(\alpha \theta-\left(1-\alpha_{j j}\right)\right) \lambda Y$, where, $Y$ is (potential) GDP, and, $\theta=\frac{(1-\beta)}{\beta}=\frac{E W^{f^{*}}}{W^{c}}$, where $W^{f^{*}}$ is "rest of the world" wealth expressed in foreign currency.

Denoting $\gamma^{*}=\left(\alpha \theta-\left(1-\alpha_{i j}\right)\right) \lambda$, then, $\delta=\gamma^{*} Y$. This means that in long run equilibrium the net international demand for the home country's assets can be expressed as a proportion $\gamma^{*}$ of its (potential or sustainable) GDP. The determinants of this factor of proportionality $\gamma^{*}$ depend on relative returns and perceived risk of country $\mathrm{j}$ and the rest of the world, as well as on the degree of integration of international financial markets.

\footnotetext{
${ }^{23}$ Most recent models on global imbalances and the U.S. current account have used a partial equilibrium framework in the simulation phase.
} 
Assuming that $g$ is the country's sustainable rate of growth, and $\pi$ is the country's (long term) rate of inflation, the "sustainable" current account deficit to GDP ratio is given by:

$$
\frac{C A D}{Y}=(g+\pi)\left(\alpha \theta-\left(1-\alpha_{j j}\right)\right) \lambda=\gamma^{*}(g+\pi) .
$$

Notice that if $\alpha \theta-\left(1-\alpha_{j j}\right)<0$, domestic residents' demand for foreign assets exceeds foreigners' demand for home country assets. Under these circumstances the country will have to run a current account surplus in order to maintain a stable net external assets' to GDP ratio. Most authors that have studied the sustainability of the U.S. current account have used equations of the type of (9) in their analyses. Mussa (2004), for example, argues that in long term equilibrium $\gamma^{*}$ is likely to be around $0.50 .{ }^{24}$ In long run equilibrium the sustainable trade balance will be given by $\frac{T D}{Y}=(g-r) \gamma^{*}$.

In this model, as in the models by Edwards (1999) and Kraay and Ventura (2002), additional savings will be allocated in a way that maintains domestic and foreign assets in the same proportion as in the original portfolio. Kraay and Ventura (2002) have shown that models that combine this assumption with the assumption of transaction costs in investment go a long way in explaining international current account behavior in a large number of countries.

If the degree of riskiness of the home country declines, there will be an increase in $\alpha$ and, thus, in $\gamma^{*}$. As a result, the sustainable current account deficit will increase, or the sustainable surplus will decline (see equation 10). Equally important, changes in portfolio allocation, generated by changes in $\alpha$ or $\alpha_{j j}$, will generate a dynamic adjustment process, during which the current account will differ from its long run sustainable level. This transitional dynamics can be incorporated into the model through the following equation:

$$
\left(\frac{C A D}{Y}\right)_{t}=(g+\pi) \gamma_{t}^{*}+\psi\left(\gamma_{t}^{*}-\gamma_{t-1}\right)-\kappa\left[\left(\frac{C A D}{Y}\right)_{t-1}-(g+\pi) \gamma_{t}^{*}\right] .
$$

24 See, also, Edwards (1995), Ades and Kaune (1997), and O'Neill and Hatzius (2004) for this type of current account sustainability analyses. 
According to equation (1) short term deviations of the current account from its long run level can result from two forces. The first is a traditional stock adjustment term $\left(\gamma_{t}^{*}-\gamma_{t-1}\right)$ that captures deviations between the demanded and the actual stock of the country's assets in hands of foreign investors. $\psi$ is the speed of adjustment, which will depend on a number of factors, including the degree of capital mobility in the country in question. The second force affecting this dynamic process, which is captured by $\kappa\left[\left(\frac{C A D}{Y}\right)_{t-1}-(g+\pi) \gamma_{t}^{*}\right]$ in equation (10), is a self-correcting term. This term plays the role of making sure that in this economy there is some form of "consumption smoothing". The importance of this self correcting term will depend on the value of $\kappa .^{25}$ Whether the dynamic representation in equation (10) is appropriate is, in the final analysis, an empirical matter. As I show in subsection III.2, below, under certain parametrization this model does a (very) good job in tracking the current account behavior in the U.S. during the last few years. The dynamic behavior for the net stock of the home country's assets in hands of foreigners, as a percentage of GDP, will be given by $\gamma_{t}^{*}=\left[\gamma_{t-1}^{*}+\left(\frac{C A D}{Y}\right)_{t-1}\right](1+g+\pi)^{-1}$.

Consider the case where for some reason the home bias in the rest of the world is reduced - that is, $\alpha$ in the portfolio equation (3) increases. This will result in an increase in the sustainable current account deficit (see equation 9). It will also unleash a dynamic adjustment process captured by equation (10). During this transitional period the current account deficit will exceed its new long run (higher) sustainable equilibrium; that is, during the transition the current account deficit will overshoot its new sustainable level. During the transition the trade account will move according to the following equation: $\Delta\left(\frac{T D}{Y}\right)_{t}=\Delta\left(\frac{C A D}{Y}\right)_{t}-\Delta\left(i \gamma_{t}^{*}\right)-\Delta\left(\left(i-i^{*}\right) \frac{F^{d}}{Y}\right)-\Delta\left(\frac{N T}{Y}\right)$. From equations (5) through (7) -- and after making some assumptions regarding the behavior of other key variables' such as the international term of trade --, the following equation for the current account

25 If $\psi=\kappa=0$, the current account will jump from one sustainable level to the next. There are many reasons to assume that both $\psi$ and $\kappa$ are different from zero, including the existence of adjustment costs in consumption. 
may be derived (in order to simplify the notation, the $m_{i}$ and $x_{i}$ have been aggregated into broad imports and exports categories):

$$
\begin{aligned}
& \Delta\left(\frac{C A D}{Y}\right)_{t}=\Delta\left(i \gamma_{t}^{*}\right)+\Delta\left(\left(i-i^{*}\right) \frac{F^{d}}{Y}\right)+\Delta\left(\frac{N T}{Y}\right)+\left\{\sigma_{x}\left(1+\varepsilon_{e}\right)-\sigma_{m}\left(1+\eta_{e}\right)\right\} \hat{e} \\
& +\left(\sigma_{m}-\sigma_{x}\right)\left(\pi-\pi^{*}\right)+\sigma_{m} \eta_{y} g-\sigma_{x} \varepsilon_{y^{*}} g^{*}+\sigma_{m} \hat{p}_{m}^{*}-\sigma_{x} \hat{p}_{x}^{*}-\left(\sigma_{m}-\sigma_{x}\right)(g+\pi) .
\end{aligned}
$$

Where $\sigma_{m}$ and $\sigma_{x}$ are imports and exports to GDP ratios; $\eta_{e}, \varepsilon_{e}$ are the price elasticities of imports and exports, respectively $\left(\eta_{e}<0, \varepsilon_{e}>0\right) . \eta_{y}, \varepsilon_{y^{*}}$ are the elasticities of imports and exports with respect to domestic and foreign income, respectively. $g, g^{*}$ represent real GDP growth at home and in the rest of the world; $\pi, \pi^{*}$ is domestic and world inflation; $\hat{p}_{m}^{*}, \hat{p}_{x}^{*}$ are the rates of changes in international prices of imports and exports, and $\hat{e}$ is the rate of change of the real exchange rate. From this equation it follows that in order for a real devaluation to improve the trade balance (and, with other things given, the current account $)$ it is required that $\left\{\sigma_{x}\left(1+\varepsilon_{e}\right)-\sigma_{m}\left(1+\eta_{e}\right)\right\}>0{ }^{26}$

Although equation (11) is not a reduced form equation, this model is useful for undertaking a number of simulation exercises. For example, form equations (2), (4), (10) and (11) -- and under assumed values of growth, inflation, interest rates and international terms of trade changes --, it is possible to analyze the way in which changes in portfolio preferences will affect the current account and real exchange rate trajectories.

\section{III.2 Simulation Results}

The bare bones model developed above may be used to compute the current account and real exchange rate adjustments consistent with shifts in portfolio preferences by foreign and domestic investors, including a reduction in the extent of home bias in portfolio investment decision. ${ }^{27}$ A first step in this analysis is the calibration of the model. In Table 7 I present the parameter values used in the base-case simulation; most

\footnotetext{
26 Under balanced initial trade, this expression becomes the traditional Marshall-Lerner condition.

27 In fact, there are indications that the process of international capital markets integration will continue in the future, as some of the largest emerging countries - including China - are increasingly allowing their nationals to invest abroad. See, for example, the Financial Times, February 28, 2005 (p.6): "China to Seek Full Currency Conversion."
} 
of these values are taken form existing studies of the U.S. and world economy. In the calibration I selected the values of $\psi$ and $\kappa$ that best tracked the actual dynamics of the current account between 1996 and 2004; the best results are obtained for $\psi=0.30$ and $\kappa=0.20$. I also assumed that foreigners' demand for U.S. assets $\alpha$ has increased gradually from 0.205 to 0.30 between 1996 and 2004 (see the values for $\alpha_{\text {Historical }}$, and $\alpha_{\text {jJInitial }}$ in Table 7). As may be seen from Figure 5.A, for the assumed parameter values the model tracks actual current account behavior for 1996-2004 quite closely.

One of the limitations of this type of simulation exercise is that it is difficult to forecast how foreign investors' net demand for U.S. assets will behave in the future. It is precisely for this reason that a number of authors have eschewed the issue, and have computed the RER adjustment "required" to eliminate completely the current account deficit. $^{28}$ In this section I take a different approach: instead of assuming that the current account deficit has to be reduced to zero - or to any other arbitrary number --, I analyze the dynamic of the current account under alternative assumptions regarding foreigner's net demand for U.S. assets. I am particularly interested in understanding what is likely to happen under an optimistic scenario, where foreigners' demand for U.S. assets continues to grow in the future. What makes this approach particularly interesting is that even under this optimistic scenario, it is highly likely that in the not too distant future the U.S. current account will undergo a significant reversal.

As may be seen in Table 7.A, in these simulation exercises I assume a gradual portfolio in the next five years: More specifically, I assume that $\alpha$ increases from its current value of 0.30 to 0.40 by 2010 ; I also assume that $\alpha_{j j}$ goes from 0.73 to 0.71 during the same period. This adjustment implies a reduction in the extent of home bias both in the rest of the world and in the U.S. In the base-case scenario the assumed portfolio adjustment is equivalent to foreigners' doubling their net demand for U.S. assets to the equivalent of $60 \%$ of U.S. GDP. This is a very large number. Indeed, it implies

28 Obstfeld and Rogoff (2000, 2004). For similar approaches see Mussa (2004) and Blanchard, Giavazzi and $\mathrm{Sa}(2005)$. 
that, under the assumptions of $g=0.03, \pi=0.023$, during the next five years (2005-2010) the U.S. NIIP would deteriorate by a further $\$ 5.72$ trillion.

Before proceeding, the following assumptions made in the base-case scenario deserve some comments (See Table 7 for details): (a) I have assumed that the U.S. and the rest of the world grow at the same rate $\left(g=g^{*}\right)$. Implicit in this assumption is the idea that while the U.S. will grow faster than Europe and Japan, the rest of the world including China and India - will continue to grow at very rapid rates. In a number of alternative simulations I considered different values for growth. (b) The values of the key elasticities have been taken from existing studies on the U.S. and global economies. ${ }^{29}$ These values reflect two important characteristics about these elasticities: the income elasticity for U.S. imports is higher than that for rest of the world imports (the so-called Houthakker-Magee effect), and the real exchange rate elasticity of U.S. imports exceeds (in absolute terms) the real exchange rate elasticity of exports by a magnitude of 3 . Finally, it is worth noting that in the base case scenario I assumed that the adjustment had no effect on the international terms of $\operatorname{trade}\left(\hat{p}_{m}^{*}=\hat{p}_{x}^{*}=0\right)$; in alternative simulations, however, I considered that case where there are changes in the terms of trade.

The results obtained from this base-case exercise are presented in Figure 5. In these simulations period 8 should be interpreted as "the initial period"; the shaded area represents recent history. Panel A depicts the current account deficit (for the first few years the actual deficit is also presented); Panel B presents the trade deficit; Panel C presents the evolution of net U.S. assets in hands of foreigners, as a percentage of U.S. GDP; and Panel D contains the simulation for the trade-weighted U.S. RER index. The most salient features of the base-case simulation may be summarized as follows:

- Under the (deliberately) optimistic assumption of a further increase in foreigners' net demand for U.S. assets, the deficit continues to increase during the next four years, until it peaks at $7.3 \%$ of GDP. From that point onwards the deficit declines towards its new steady state of $3.18 \%$ of GDP.

29 See Hooper, Johnson and Marquez (2001). 
- Once the deficit reaches its peak, the current account reversal is quite sharp. According to the base-case scenario, during the first three years of adjustment the current account is reduced by $3.2 \%$ of GDP. The reversal of the trade deficit is even sharper. The reason for this is that with a higher net debtor position, net payments (interest and dividends) to foreign investors increase significantly, relative to GDP.

- As may be seen from Panel D, once the process of current account reversal begins, the trade-weighted RER index experiences a rapid (real) depreciation. During the first three first yeas of the adjustment the accumulated real depreciation is $21.3 \%$. By the time the new sustainable current account deficit is reached, the accumulated depreciation of the trade-weighted RER index amounts to $28 \%$. This result is roughly in line with other studies on the subject (See Table 6 for details on other studies). It should be noted that these simulations incorporate the valuation effect of dollar depreciation on the U.S. net foreign asset position. If the valuation effect is ignored, the resulting real depreciation is larger. For example, in the first three years of the adjustment the accumulated depreciation is $28.3 \%$.

Naturally, these simulation results depend on the assumptions summarized in Table 7. Alternative assumptions regarding growth, inflation, interest rates, terms of trade, elasticities and other key parameters will affect the quantitative aspect of the simulations. To the extent that the changes in the assumptions are not extreme, however, the main qualitative result holds: even under a (very) optimistic assumption regarding foreigners' net demand for U.S. assets, the current account deficit is likely to go through a large reversal in the not too distant future.

An important question is how sensitive are these results to portfolio choices. In order to explore this issue, in Figure 6 I report results from a simulation exercise (Simulation B) that assumes that after increasing their net holdings of U.S. assets to $60 \%$ of U.S. GDP by the year 2010, foreign investors make a new portfolio adjustment, and gradually reduce their desired holdings of U.S. assets to "only" 50\% of GDP by 2010. 
As may be seen from Figure 6, in this case the current account reversal is significantly more abrupt, as is the depreciation of the trade-weighted RER index. In the first three years of the adjustment the current account deficit declines by 5.3\% of GDP, and the accumulated depreciation is $28.8 \%$. Moreover, as may be seen in Figure 6.D, by the third year of the adjustment (period 15 in the simulation) the trade balance has turned into a trade surplus. It is important to keep in mind that this simulation still assumes that the long run net demand by foreigners for U.S. assets is still significantly higher - $20 \%$ of GDP higher, to be more precise - than its current level. Due to space considerations, I have not presented the results from "pessimistic" scenarios, where foreigners' reduce their net demand for U.S. assets below the current level. Suffice is to say that under that scenario the current account reversal is even more pronounced, as is the concomitant real depreciation.

The results in Figures 5 and 6, -- and in particular the abrupt current account reversal that takes place after a peak deficit is reached -- depend on the assumptions made on parameters $\psi$ and $\kappa$; different values of these parameters would result in different dynamics. More specifically, a very large value of $\psi$, coupled with a very low value of $\kappa$ would result in a more gradual convergence of the current account deficit to its new sustainable level. It should be noticed, however, that in this case the build-up of the deficit is also very gradual, and does not track the actual experience of the U.S. since the mid-1990s. Indeed, the values of $\psi$ and $\kappa$ used in the simulations are those that provide a better representation of the U.S. recent history.

The simulations discussed above have assumed an exogenously given rate of growth of GDP. This, of course, needs not be the case. It is likely, in fact, that current account reversals of the type and magnitude suggested by the simulation results will have an effect on real economic activity, including growth. ${ }^{30}$ In Section IV of this paper I use a new comparative cross country data set to investigate the real consequences of current account reversals in the world economy since 1971. This comparative analysis will be useful to get some idea on the possible effects of a potential U.S. current account reversal, similar to that in the simulations in Figures 5 and 6.

30 See the pioneering study on current account reversals by Milesi-Ferreti and Razin (2000). See, also, Edwards (2004). 


\section{How Costly are Current Account Reversals? An International Comparative Analysis}

The main message from the simulation exercises presented in the preceding section is that, even under very optimistic scenarios where foreigners' demand for U.S. assets increases significantly, it is very likely that the U.S. current account will experience a significant reversal in the not too distant future. A key question is what will be the nature of this adjustment process? In this section I address this issue by analyzing the international experience with current account reversals in the period 1971-2001. Although the U.S. case is unique - both because of the size of its economy and because the dollar is the main vehicle currency in the world -, an analysis of the international experience will provide some light on the likely nature of the adjustment. A particularly important question is whether this adjustment will entail real costs in the form of lower growth and higher unemployment. Previous studies on the subject have generated conflicting results: after analyzing the evidence from a large number of countries, MilesiFerreti and Razin (2000) concluded that major current account reversals have not been costly. According to them, "reversals... are not systematically associated with a growth slowdown (p. 303)." Frankel and Cavallo (2004), on the other hand, concluded that sudden stops of capital inflows (a phenomenon closely related to reversals) have resulted in growth slowdown.

In what follows I analyze several aspects of current account reversals, including: ${ }^{31}$

- Incidence of current account reversals.

- Relationship between reversals and sudden stops of capital inflows.

- The relation between current account reversals and exchange rate depreciation.

- The factors determining the probability of a country experiencing a current account reversal.

- The costs - in terms of growth slowdown - of current account reversals.

\footnotetext{
31 In Edwards (2004) I used a smaller data set to investigate reversals in emerging countries. In that paper, however, I did not consider the experience of large or industrial countries with reversals. Also, in that paper I used very simple framework for analyzing growth. In contrast, in this section I use a two steps dynamic of growth approach.
} 
In analyzing these issues I rely on two complementary statistical approaches: First, I use non-parametric tests to analyze the incidence and main characteristics of current account reversals. And second, I use panel regression-based analyses to estimate the probability of experiencing a current account reversal, and the cost of such reversal, in terms of short-term declines in output growth. Although the data set covers all regions in the world, in the discussion presented in this section, and in an effort to shed light on the U.S. case, I emphasize the experience of large countries.

\section{IV.1 Current Account Reversals during 1971-2001: The International Evidence}

I use two definitions of current account reversals: (a) Reversal I is defined as a reduction in the current account deficit of at least $6 \%$ of GDP in a three-year period. (b) Reversal II is defined as a reduction in the current account deficit of at least $4 \%$ of GDP in one year. ${ }^{32}$ In Reversal I the magnitude of the adjustment is more pronounced, but is distributed over a longer number of years than under the Reversal I definition. ${ }^{33}$ In Table 8 I present data on the incidence for both definitions of current account reversals for the complete sample as well as for the six groups of countries considered in Section III. As may be seen, for the overall sample the incidence of reversals is $9.2 \%$ and $11.8 \%$, for Reversals I and II, respectively. The incidence of reversals among the industrial countries is much smaller however, at $2.7 \%$ and $2.0 \%$ for Reversals I and II. Indeed, the Pearson- $\chi^{2}$ and F-tests reported in Table 8 indicate that the hypothesis of equal incidence of reversals across regions is rejected strongly.

The advanced countries that have experienced current account Reversals I are: Finland (1978, 1994), Greece (1988), Ireland (1984), New Zealand (1977-78, 1988-89), Norway (1979-80, 1989, 2000) and Portugal (1979, 1984-85). The advanced countries that have experienced current account Reversals II are: Austria (1982), Canada (1982), Greece (1986), Iceland (1983, 1986), Ireland (1975), Italy (1975), Malta (1997), New Zealand (1978), Norway (1989), and Portugal (1982-83, 1985). With the exception of

\footnotetext{
32 In both cases the timing of the reversal is recorded as the year when the episode ends. That is if a country reduces its current account deficit by 7\% of GDP between 1980 and 1982, the episode is recorded has having taken place in 1982. Also, for a particular episode to classify as a current account deficit reversal, the initial balance has to be indeed a deficit. Notice that these definitions are somewhat different from those used in other studies, including Freund (2000), Milesi-Ferreti and Razin (2000), Edwards (2002) and Guidotti et al (2003).

${ }^{33}$ Notice that it is possible for a country to have experienced both a Reversal I and II during a same historical episode.
} 
Italy and Canada, all of these countries are very small, underlying the point that there are no historical precedents of large countries undergoing profound current account adjustments. As pointed out above, this implies that the results reported here on current account reversals should be interpreted with a grain of salt, and should not be mechanically extended to the case of the U.S.

The analysis presented above has distinguished countries by their stage of development and geographical location. An alternative way of dividing the sample - and one that is particularly relevant for the discussion of possible lessons for the U.S. - is by country size. I define "large countries" as those having a GDP in the top $25 \%$ of the distribution (according to this criterion there are 44 "large" countries in the sample). The incidence of Reversals I among "large" countries is 3.6\% for 1971-2001; the incidence of Reversals II among "large" countries is $5.9 \%$.

\section{IV.1.1 Current Account Reversals and Sudden Stops of Capital Inflows}

In the last few years a number of authors have analyzed episodes of sudden stops of capital inflows into a country. ${ }^{34}$ From an analytical perspective sudden stops and current account reversals should be highly related phenomena. There is no reason, however, for their relationship to be one-to-one. Indeed, because of changes in international reserves, it is perfectly possible that a country that suffers a sudden stop does not experience, at the same time, a current account reversal. However, in countries with floating exchange rates changes in international reserves tend to be relatively small and, at least in principle, the relation between sudden stops and reversals should be stronger.

In order to investigate formally the relation between these two phenomena I defined a "sudden stop" episode as an abrupt and major reduction in capital inflows to a country that up to that time had been receiving large volumes of foreign capital. More specifically, I imposed the following requirements for an episode to qualify as a "sudden stop": (1) the country in question must have received an inflow of capital (relative to GDP) larger than its region's third quartile during the two years prior to the "sudden

\footnotetext{
${ }^{34}$ See Calvo et al (2004), Edwards (2004b).
} 
stop." And (2), net capital inflows must have declined by at least 5\% of GDP in one year. ${ }^{35}$

In Table 9 I present a table for the "sudden stops" and the current account deficit reversal (I use both definitions of reversal), for three samples: (a) large countries, defined as those countries that whose GDP is in the top quartile of the distribution; (b) industrial countries; and (c) the complete sample. Table 9 shows that for the complete sample, $21.1 \%$ of countries subject to a sudden stop also faced a Type I current account reversal. At the same time, $15.0 \%$ of those with Reversals I also experienced (in the same year) a sudden stop of capital inflows. Panel C shows that $51 \%$ of countries subject to a sudden stop faced a current account reversal II. Also, $26.7 \%$ of those with Reversals II experienced (in the same year) a sudden stop of capital inflows. The $\chi^{2}$ tests indicate that in both cases the hypothesis of independence between reversals and sudden stops is rejected. The data for the industrial countries show that the joint incidence of Reversals I and Sudden Stops is rather low. In fact, according to the $\chi^{2}$ test the null hypothesis of independence between the two phenomena cannot be rejected. The relation between sudden stops and Reversals II is somewhat higher for industrial countries: the hypothesis of independence is rejected $\left(\chi^{2}=23.6 ; p=0.00\right)$. The results for "large countries" are similar to that for industrial countries.

An analysis of the lead-lag structure of reversals and sudden stops suggest that sudden stops tend to occur either before or at the same time - that is, during the same year - as current account reversals. Indeed, according to a series of non-parametric $\chi^{2}$ tests it is possible to reject the hypothesis that current account reversals precede sudden stops.

\section{IV.2 Current Account Reversals and the Exchange Rate}

An important policy question - and one that is particularly relevant within the context of current policy debate in the U.S. - is whether current account reversals have historically been associated with unusually large exchange rate depreciations. The starting point for this analysis is the construction of an index of "external pressures" along the lines suggested by Eichengreen et al (1996):

\footnotetext{
${ }^{35}$ In order to check for the robustness of the results, I also used two alternative definitions of sudden stops, which considered a reduction in inflows of 3 and 7 of GDP in one year. Due to space considerations, however, I don't report detailed results using these definitions.
} 


$$
I_{t}=\Delta E / E-\left(\sigma_{E} / \sigma_{R}\right) *(\Delta R / R) .
$$

Where $(\Delta E / E)$ is the rate of change of the nominal exchange rate, and $(\Delta R / R)$ is the rate of change of international reserves. $\sigma_{E}$ is the standard deviation of changes in exchange rates, and $\sigma_{R}$ is the standard deviation of changes in international reserves. Traditional analyses define a crisis $\left(C_{t}\right)$ to have taken place when the index in equation (12) exceeds the mean of the index plus k standard deviations. The crisis indicator $C_{t}$ takes a value of one (crisis) or zero (no crisis) according to the following rule: ${ }^{36}$

$$
C_{t}=\left\{\begin{array}{ccc}
1 & \text { if } & I_{t}>=\text { mean }\left(I_{t}\right)+k \sigma_{I} \\
0 & \text { otherwise }
\end{array}\right.
$$

Based on equation (13), I define two currency crisis indicators: (a) Currency Crisis A: This is the traditional crises index. $C_{t}$ takes the value of one if $I_{t}$ exceeds its mean by 3 times its standard deviation (that is, $k=3$ in equation 13). (b) Currency Crisis B: In this case it is the nominal exchange rate by itself that triggers the $C_{t}$ crisis indicator. In this case the country experiences a large exchange rate depreciation without a major loss in international reserves. This indicator is more relevant for the case of floating exchange rate countries, where changes in international reserves are minimal.

I computed a number of two-way frequency tables and both definitions of crisis and of current account reversals. I also calculated $\chi^{2}$ tests for independence of occurrence of these phenomena. In Table 10 I present data on the percentage of current account reversals that also correspond to crises. The results are for three samples: large countries, industrial countries, and all countries. As above, I have defined "large countries" as having a GDP in the top $25 \%$ of the distribution. ${ }^{37}$ The results obtained suggest that historically there have been a number of cases where current account reversals and currency crisis have occurred jointly. Consider, for example, the case of Currency Crises $A$ and Reversals I for the large countries sample: $34.6 \%$ of countries with reversals

\footnotetext{
${ }^{36}$ The pioneer work here is Eichnegreen et al (1996), who suggested that the index (12) also included changes in domestic interest rates. The original index, however, has limited use in broad comparative analyses; the reason for this is that most emerging and transition economies don't have long time series on interest rates. For this reason, most empirical analyses are based on a restricted version of the index, such as 2 .

${ }^{37}$ Data on the percentage of crises that also correspond to reversals are available on request. The results of the $\chi^{2}$ tests confirm those discussed above.
} 
experienced a contemporaneous currency crisis; $46.4 \%$ experienced a crisis in the second year of the reversal episode; and $28.6 \%$ of the reversals experienced a type $A$ currency crisis in the third (and final) year of the reversal episode. For the case of industrial countries the data in Table 10 shows that countries with reversals tended to experience currency crises during the initial year of the reversal episode. As may be seen from Table 10 , the $\mathrm{p}$-values for the $\chi^{2}$ tests indicate that, in most cases, the null hypothesis that current account reversals and currency crises are independent from each other is rejected at conventional levels. Even though these tests don't imply causality, they do provide evidence indicating that historically countries that have gone through major current account reversals have tended to also experience currency crises.

In Table 11 I present data on the distribution of exchange rate changes for Type I current account reversal countries. ${ }^{38}$ Panel A contains data on the nominal exchange rate (relative to the U.S. dollar); Panel B is for the (trade-weighted) real exchange rate. These changes are calculated as the accumulated exchange rate change in the period comprised between the year of the reversal and three years before the reversal. In Panel A a positive number indicates a nominal depreciation. For comparison purposes I have also included the distribution of three year nominal exchange rate changes for a control group of countries that have not experienced a current account reversal. The results in Table 11.A, indicate that reversal countries have tended to experience significantly larger nominal depreciations than the control group of countries. Consider, for example, the case of large countries: the average depreciation for the reversal episodes - the "treatment" column -- is $28 \%$; it is only 9.2 for the control group of countries. In order to test formally whether nominal exchange rate changes behaved differently in reversal and control group countries, I estimated a series of non parametric Kruskal-Wallis $\chi^{2}$ tests on the equality of the distribution of the accumulated depreciation. The null hypothesis is that the data from the reversal countries and from the control group have been drawn from the same population. As may be seen from Table 11, in the vast majority of cases the null hypothesis is rejected at conventional levels.

\footnotetext{
38 Data on Reversal II countries are not presented due to space considerations. The results, however, are similar to those reported here, and are available on request.
} 
Table 11.B present data for the accumulated change in the RER for the reversal countries and the control group of countries. The results indicate that large countries experienced a rather small real depreciation $(3.1 \%)$ in the period surrounding the current account adjustment. The magnitude of the average RER depreciation is, however, statistically larger than the average depreciation for the control group (See the $\mathrm{p}$-value for the $\chi^{2}$ test). The same is true for the "all countries" sample. Surprisingly, perhaps, for the industrial countries the accumulated average change in the RER is an appreciation.

The average accumulated depreciations (both nominal and real) in the reversal countries reported in Table 11 are relatively small when compared with the "required" exchange rate depreciation that has been calculated in a number of studies, including in the simulations reported in Section III of this paper. Obstfeld and Rogoff (2004), for example, estimate that eliminating the U.S. current account deficit would imply a (real) depreciation of between 16 and 36 percent. Blanchard, Giavazzi and Sa (2005) have estimated a required depreciation of the U.S. trade weighted dollar in the range of $40 \%$ to $90 \%$. There are many possible reasons for these differences, including that the U.S is a very large country, while the countries that have experienced reversals are much smaller. Also, the values of elasticities and other parameters may be different in the U.S. than in the average reversal country. Yet another possibility has to do with the level of economic activity and aggregate demand. Most recent models on the U.S. current account assume that the economy stays in a "full employment" path. It is possible, however, that the countries that have historically experienced reversals have also gone through economic slowdowns, and that a reduction in aggregate demand contributed to the adjustment effort.

\section{IV.3 The Probability of Experiencing Current Account Reversals}

In order to understand further the forces behind current account reversals I estimated a number of panel equations on the probability of experiencing a reversal. The empirical model is given by equations (14) and (15): 


$$
\begin{aligned}
& \rho_{t j}=\left\{\begin{array}{cc}
1, & \text { if } \rho_{t j}^{*}>0, \\
0, & \text { otherwise. }
\end{array}\right. \\
& \rho_{t j}^{*}=\alpha \omega_{t j}+\varepsilon_{t j} .
\end{aligned}
$$

Variable $\rho_{j t}$ is a dummy variable that takes a value of one if country $\mathrm{j}$ in period $\mathrm{t}$ experienced a current account reversal, and zero if the country did not experience a reversal. According to equation (15), whether the country experiences a current account reversal is assumed to be the result of an unobserved latent variable $\rho_{t j}^{*}$. $\rho_{t j}^{*}$, in turn, is assumed to depend linearly on vector $\omega_{t j}$. The error term $\varepsilon_{t j}$ is given by given by a variance component model: $\varepsilon_{t j}=v_{j}+\mu_{t j} . \quad v_{j}$ is iid with zero mean and variance $\sigma_{v}^{2}$; $\mu_{t j}$ is normally distributed with zero mean and variance $\sigma_{\mu}^{2}=1$. The data set used covers 87 countries, for the 1970-2000 period; not every country has data for every year, however. See the Data Appendix for exact data definition and data sources.

In determining the specification of this probit model I followed the literature on external crises, and I included the following covariates: ${ }^{39}$ (a) The ratio of the current account deficit to GDP lagged one period. (b) A sudden stop dummy that takes the value of one if the country in question experienced a sudden stop in the previous year. (c) An index that measures the relative occurrence of sudden stops in the country's region (excluding the country itself) during that particular year. This variable captures the effect of "regional contagion." (d) The one-year lagged gross external debt over GDP ratio. Ideally one would want to have the net debt; however, there most countries there are no data on net liabilities. (e) The one-year lagged rate of growth of domestic credit. (f) The lagged ratio of the country's fiscal deficit relative to GDP. (g) The country's initial GDP per capita (in logs).

The results obtained from the estimation of this variance-component probit model for a sample of large countries are presented in Table 12; as before, I have defined

\footnotetext{
39 See, for example, Frankel and Rose (1996), Milesi-Ferreti and Razin (2000) and Edwards (2002).
} 
"large" as having a GDP in the top $25 \%$ of its distribution. The results obtained are quite satisfactory; the vast majority of coefficients have the expected sign, and most of them are significant at conventional levels. The results may be summarized as follows: Larger (lagged) current account deficits increase the probability of a reversal, as does a (lagged) sudden stop of capital inflows. Countries with higher GDP per capita have a lower probability of a reversal. The results do not provide strong support for the contagion hypothesis: the variable that measures the incidence of sudden stops in the county's region is significant in only one of the equations (its sign is always positive, however). There is also evidence that an increase in a country's (gross) external debt increases the probability of reversals. The results also indicate that higher public sector deficits result in an increase in the probability of a Reversal II. Countries with looser monetary policy also have had a higher probability of experiencing a reversal. Although, the U.S. is a very special case the results reported in Table 12 provide some support to the idea that during the last few years the probability of the U.S. experiencing a reversal has increased: indeed, the U.S. has experienced steady increases in some important determinants of reversals, such as its (gross) international debt, its fiscal deficit and its current account deficit.

\section{IV.4 Current Account Reversals and Growth}

In this subsection I investigate the relation between current account reversals and real economic performance. I am particularly interested in analyzing in analyzing the following issues: (a) historically, have abrupt current account adjustments had an effect on GDP growth? (b) Have sudden stops and current account reversals had the same impact on growth? And (c), have the effects of reversals depend on the structural characteristics of the country in question, including its economic size (i.e. whether it is a large country), its degree of trade openness and the extent to which it restricts capital mobility. In addressing these issues I emphasize the case of large countries; as a comparison, however, I do provide results for the complete sample of large and small countries.

Authors that have analyzed the real effects of current account reversals have reached different conclusions. Milesi-Ferreti and Razin (2000), for example, used both before-and-after analyses as well as cross-country regressions to deal with this issue and 
concluded that "reversal events seem to entail substantial changes in macroeconomic performance between the period before and the period after the crisis but are not systematically associated with a growth slowdown (p. 303, emphasis added)." Edwards (2002), on the other hand, used dynamic panel regression analysis and concluded that major current account reversals had a negative effect on investment, and that they had "a negative effect on GDP per capita growth, even after controlling for investment (p. 52)."40

\section{IV.4.1 Growth Effects of Current Account Reversals and Sudden Stops: An Econometric Model}

The point of departure of the empirical analysis is a two-equation formulation for the dynamics of real GDP per capita growth of country $\mathrm{j}$ in period t. Equation (16) is the long run GDP growth equation; equation (17), on the other hand, captures the growth dynamics process.

$$
\begin{aligned}
& \tilde{g}_{t}=\alpha+x_{j} \beta+r_{j} \theta+\omega_{j} . \\
& \Delta g_{j t}=\lambda\left[\tilde{g}_{j}-g_{j t-1}\right]+\varphi v_{j t}+\mu_{j t}+\varepsilon_{j t} .
\end{aligned}
$$

I have used the following notation: $\tilde{g}_{j}$ is the long run rate of real per capita GDP growth in country $\mathrm{j} ; x_{j}$ is a vector of structural, institutional and policy variables that determine long run growth; $r_{j}$ is a vector of regional dummies; $\alpha, \beta$ and $\theta$ are parameters, and $\omega_{j}$ is an error term assumed to be heteroskedastic. In equation (17), $g_{j t}$ is the rate of growth of per capita GDP in country $\mathrm{j}$ in period t. The terms $v_{j t}$ and $u_{j t}$ are shocks, assumed to have zero mean, finite variance and to be uncorrelated among them. More specifically, $v_{j t}$ is assumed to be an external terms of trade shock, while $u_{j t}$ captures other shocks, including current account reversals and sudden stops of capital inflows. $\varepsilon_{j t}$ is an error term, which is assumed to have a variance component form, and $\lambda, \varphi$, and $\gamma$ are parameters that determine the particular characteristics of the growth process. Equation (17) has the form of an equilibrium correction model and states that the actual

\footnotetext{
${ }^{40}$ In a recent paper, Guidotti et al (2003) consider the role of openness in an analysis of imports and exports behavior in the aftermath of a reversal. See also Frankel and Cavallo (2005).
} 
rate of growth in period $t$ will deviate from the long run rate of growth due to the existence of three types of shocks: $\mathrm{v}_{\mathrm{tj}}, \mathrm{u}_{\mathrm{tj}}$ and $\xi_{\mathrm{tj}}$. Over time, however, the actual rate of growth will tend to converge towards it long run value, with the rate of convergence given by $\lambda$. Parameter $\varphi$, in equation (17), is expected to be positive, indicating that an improvement in the terms of trade will result in a (temporary) acceleration in the rate of growth, and that negative terms of trade shock are expected to have a negative effect on $g_{j t} \cdot{ }^{41}$ From the perspective of the current analysis, a key issue is whether current account reversals and sudden stops have a negative effect on growth; that is, whether coefficient $\gamma$ is significantly negative. In the actual estimation of equation (17), I used dummy variables for sudden stops and reversals. An important question - and one that is addressed in detail in the Subsection that follows - is whether the effects of different shocks on growth are different for countries with different structural characteristics, such as its degree of trade and capital account openness.

Equations (16) - (17) were estimated using a two-step procedure. In the first step I estimate the long run growth equation (16) using a cross-country data set. These data are averages for 1974-2001, and the estimation makes a correction for heteroskedasticity. These first stage estimates are then used to generate long-run predicted growth rates to replace $\widetilde{g}_{j}$ in the equilibrium error correction model (17). In the second step, I estimated equation (17) using GLS for unbalanced panels; I used both random effects and fixed effects estimation procedures. ${ }^{42}$ The data set used covers 157 countries, for the 19702000 period; not every country has data for every year, however. See the Data Appendix for exact data definition and data sources.

In estimating equation (16) for long-run per capita growth, I followed the standard literature on growth, as summarized by Barro and Sala-I-Martin (1995), Sachs and Warner (1995) and Dollar (1992) among others. I assume that the rate of growth of GDP $\left(\widetilde{g}_{j}\right)$ depends on a number of structural, policy and social variables. More specifically, I include the following covariates: the log of initial GDP per capita; the investment ratio; the coverage of secondary education, as a proxy for human capital; an index of the degree

41 See Edwards and Levy Yeyati (2004) for details.

42 Due to space considerations, only the random effect results are reported. 
of openness of the economy; the ratio of government consumption relative to GDP; and regional dummies. The results obtained from these first-step estimates are not reported due to space considerations.

In Table 13 I present the results from the second step estimation of the growth dynamics equation (17), when random effects were used. The results are presented for the "large countries" sample (Panel A), as well as for the "all countries" sample (Panel B). The first two equations refer to current account reversals (Reversals I and II, respectively). In the next equation I have included the sudden stops indicator instead of the reversal dummy. In equations (13.4) and (13.5) I included both the sudden stops and the reversals variables as regressors. ${ }^{43}$ The estimated coefficient of the growth gap is, as expected, positive, significant, and smaller than one. The point estimates are on the high side -- between 0.71 and 0.82 --, suggesting that, on average, deviations between long run and actual growth get eliminated rather quickly. For instance, according to equation (13.1), after 3 years approximately $85 \%$ of a unitary shock to real GDP growth per capita will be eliminated. Also, as expected, the estimated coefficients of the terms of trade shock are always positive, and statistically significant, indicating that an improvement (deterioration) in the terms of trade results in an acceleration (de-acceleration) in the rate of growth of real per capita GDP. As may be seen from equations (13.1) and (13.2), the coefficient of the current account reversals variable is significantly negative, indicating that reversals result in a deceleration of growth. For large countries these results suggest that, on average, a Type I reversal has resulted in a reduction of GDP growth of $3.2 \%$. This effect persists through time, and gets eliminated gradually as $g$ converges towards $\tilde{g}_{j}$. In the case of Reversal II the estimated negative effect is even larger, at $-4.6 \%$. The results in equation (13.3) show that countries that have experienced a sudden stop of capital inflows have also experienced a reduction in GDP growth - for large countries the point estimate is -1.5 . This is the case independently of whether the country in question has also suffered from a current account reversal. In the last two equations in Table $13 \mathrm{I}$ included both the current account reversal and sudden stops indicators. The results obtained suggest that the larger costs of adjustment have been associated with current

\footnotetext{
${ }^{43}$ In the analysis that follows, and in order to focus the discussion, I will concentrate on the effects of current account reversals.
} 
account reversals. Take, for example, equation (13.4) for the large countries sample: the coefficient of Reversal I is more than twice as large (in absolute terms) than that of sudden stops. According to this equation, countries that have experienced both a reversal and a sudden stop experienced, on average, a decline in GDP per capita growth of 5\%. In equation (13.5) the coefficient of the current account reversal indicator continues to be significantly negative; the coefficient of sudden stops is negative but not significant.

To summarize, the results presented in Table 13 are revealing, and provide some light on the costs of an eventual current account reversal in the U.S. Historically, "large countries that have gone through reversals have experienced deep GDP growth reductions. These estimates indicate that, on average, and with other factors given, the declined of GDP growth per capita has been in the range of 3.6 to 5.0 percent in the first year of the adjustment. Three years after the initial adjustment GDP growth will still be below its long run trend.

\section{IV.4.2 Extensions, Endogeneity and Robustness}

In this sub-section I discuss some extensions and deal with robustness issues, including the potential endogeneity bias of the estimates. More specifically, I address the following issues: (a) the role of countries structural characteristics in determining the costs of adjustment; (b) results from instrumental variables random effect GLS estimation; and (c) the effects of terms of trade changes;

A. Openness and the Costs of Adjustment: Recent studies on the economics of external adjustment have emphasized the role of trade openness. Edwards (2004), Calvo et al (2004) and Frankel and Cavallo (2004), among others, have found that countries that are more open to international trade tend to incur in a lower cost of adjustment. These studies, however, have not made a distinction between large and small countries, nor have they distinguished between openness in the trade account and openness in the capital account. In order to investigate whether openness has historically affected the cost of external adjustment in large countries I added two interactive regressors to equations of the type of (17). More specifically, I included the following terms: (a) a variable that interacts the reversals indicator with trade openness (measure as exports plus imports over GDP); and (b) a variable that interacts the reversal indicator with an index of the degree of international capital mobility. This index was developed by Edwards 
(2005), and ranges from zero to 100, with higher numbers denoting a higher degree of capital mobility. The results obtained are presented in Table 14. As may be seen, the coefficients of the reversal indicators continue to be significantly negative, as in Table 13. However, and in contrast with previous results obtained in other studies for broad samples of all countries - small and large; emerging and advanced - the variable that interacts trade openness and reversals is significantly negative, indicating that for large countries trade openness tends to amplify, rather than reduce, the negative effect of a current account reversal on growth. The coefficient for the variable that interacts reversals with capital mobility is significantly positive in equation (14.1), suggesting that large countries that have a higher degree of capital mobility experience a smaller cost of adjustment than countries that restrict capital mobility. In equation 14.2, however, the coefficient of this interactive variable is not significant.

B. Endogeneity and Instrumental Variables Estimates: The results discussed above were obtained using a random effects GLS for unbalanced panels, and under the assumption that the reversal variable is exogenous. It is possible, however, that whether a reversal takes place is affected by growth performance, and, thus, is endogenously determined. In order to deal with this issue I have re-estimated equation (17) using an instrumental variables GLS panel procedure. In the estimation the following instruments were used: (a) the ratio of the current account deficit to GDP lagged one and two periods. (b) A lagged sudden stop dummy that takes the value of one if the country in question has experienced a sudden stop in the previous year. (c) An index that measures the relative occurrence of sudden stops in the country's region (excluding the country itself) during that particular year. This variable captures the effect of "regional contagion." (d) The one-year lagged external gross debt over GDP ratio. (e) The ratio of net international reserves to GDP, lagged one year. (f) The one-year lagged rate of growth of domestic credit. (g) The country's initial GDP per capita (in logs). The results obtained are presented in Table 15. As may be seen, the coefficients of the reversal indicators are significantly negative, confirming that historically current account reversals have had a negative effect on growth. The absolute value of the estimated coefficients, however, are larger than those obtained when random effects GLS were used (See Table 13A). 
C. Terms of Trade Effects: The results in Table 13 were obtained controlling for terms of trade changes. That is, the coefficient of the Reversal I and II coefficients capture the effect of a current account reversal maintaining terms of trade constant. As discussed in Sections II and III, however, in large countries external adjustment is very likely to affect the terms of trade. The exact nature of that effect will depend on a number of factors, including the size of the relevant elasticities and the extent of home bias in consumption. In order to have an idea of the effect of current account reversals allowing for international price adjustments, I re-estimated equation (17) excluding the terms of trade variable for the "large countries" sample (detailed results not reported due to space constraints). The estimated coefficients for the reversals coefficients were smaller (in absolute terms) than those in Table 12A. The estimated coefficient of the Reversal I is now -2.43 (it is -3.81 in Table 13A). The new estimated coefficient of Reversal II is now -3.63 ; it was -4.61 in Table 13A). This suggests that for the sample in this paper external adjustment has been associated, on average, with an improvement in the international terms of trade.

D. Robustness and Other Extensions: In order to check for the robusteness of the results I also estimated several versions of equation (17) for the large countries sample. In one of these exercises I introduced lagged values of the reversal indicators as additional regressors. The results obtained - available on request - show that lagged values of these indexes were not significant at conventional levels. I also varied the definition of "large countries;" the main message of the results, however, is not affected by the sample.

\section{Concluding Remarks}

In this paper I have illustrated the uniqueness of the current U.S. external situation. Never in the history of modern economics has a large industrial country run persistent current account deficits of the magnitude posted by the U.S. since 2000. These developments can be explained in the context of a portfolio model of the current account, where for a number of reasons - the end of the Cold War, the internet revolution, and the liberalization of international capital movements in most countries -- foreign investors' increase their (net) demand for U.S. assets. Indeed, by increasing their demand for U.S. 
assets from 305 to $40 \%$ of their wealth, foreigners have provided American residents with the needed funds to run the large deficits of the last few years.

The future of the U.S. current account - and thus of the U.S. dollar - depend on whether foreign investors will continue to add U.S. assets to their investment portfolios. As a way of sharpening the discussion, in this paper I have deliberately made a (very) optimistic assumption: I have assumed that during the last five years foreigners' (net) demand for U.S. assets (as a proportion of U.S. GDP) doubles relative to its current level. The simulation model indicates that even under this optimistic assumption, in the not too distant future the U.S. will have to go through a significant adjustment in (the not too distant) future. Indeed, it is not possible to rule out a scenario where the U.S. current account deficit would shrink abruptly by 3 to 6 percent of GDP. According to the simulations, this type of adjustment would imply an accumulated real depreciation of the trade-weighted dollar in the range of $21 \%-28 \%$ during the firs three years of the adjustment.

In order to have an idea of the possible consequences of this type of adjustment, I analyze the international evidence on current account reversals. The results from this empirical investigation indicate that major current account reversals have tended to result in large declines in GDP growth. Historically, "large countries" that have gone through major reversals have experienced deep GDP growth reductions. These estimates indicate that, on average, and with other factors given, the declined of GDP growth per capita has been in the range of 3.6 to 5.0 percent in the first year of the adjustment. Three years after the initial adjustment GDP growth will still be below its long run trend.

Although the results presented in this paper are revealing, and suggest that the U.S. is likely to experience a painful and costly adjustment in the not too distant future, there many questions still unresolved. These include:

- The behavior of foreign central banks, including their future demand for U.S. assets. A particularly important question is central banks' appropriate international reserve policy in a world where most exchange rates have (at least) some flexibility. A number of analysts are concerned that the Asian central banks would reduce their demand of U.S. assets, unleashing an abrupt collapse in the value of the dollar. 
- We need a better understanding of the way adjustment works in large countries. Although in Section IV I concentrated on the case of large countries, the nations in that sample that experienced current account reversals are much smaller than the U.S. In particular, there is need to analyze the potential interest rate consequences of a major U.S. current account adjustment.

- Most models on the U.S. current account imbalance - including the portfolio model in Section III -- have focused on the RER. Estimating the adjustment in the nominal exchange rates is not trivial, however. The actual adjustment will depend on the pass through coefficient, as well as on exchange rate policies followed by some important U.S. trade partners, including China, Japan and other Asian countries. 
Figure 1: Real Exchange Rate and Current Account

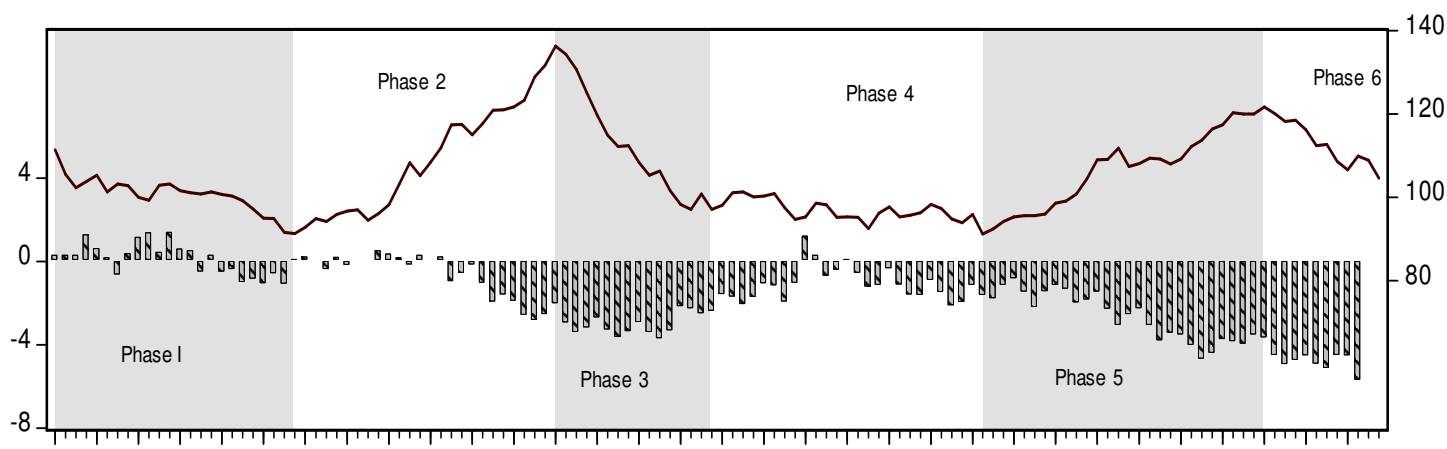

$\begin{array}{llllllllllllllllllllllllllllllllll}73 & 74 & 75 & 76 & 77 & 78 & 79 & 80 & 81 & 82 & 83 & 84 & 85 & 86 & 87 & 88 & 89 & 90 & 91 & 92 & 93 & 94 & 95 & 96 & 97 & 98 & 99 & 00 & 01 & 02 & 03 & 04\end{array}$

AN Current Account to GDP (Left Axis)

- Real Exchange Rate (Right Axis) 
Figure 2: Components of Current Account Deficit, 1946-2004

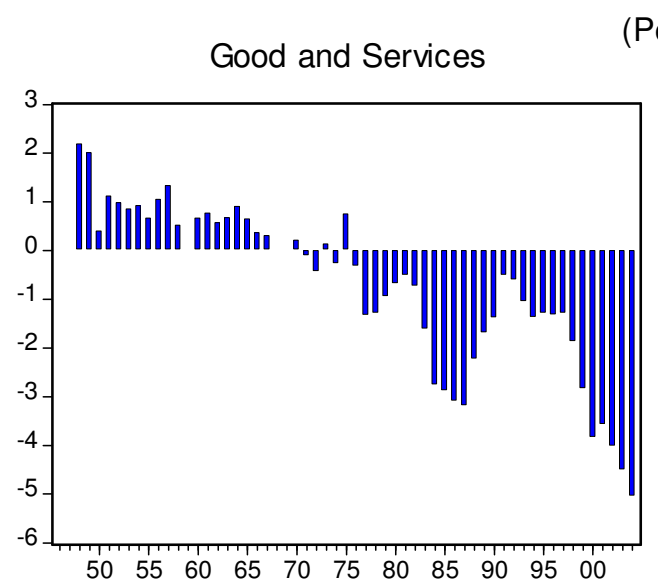

(Percent of GDP)

Services
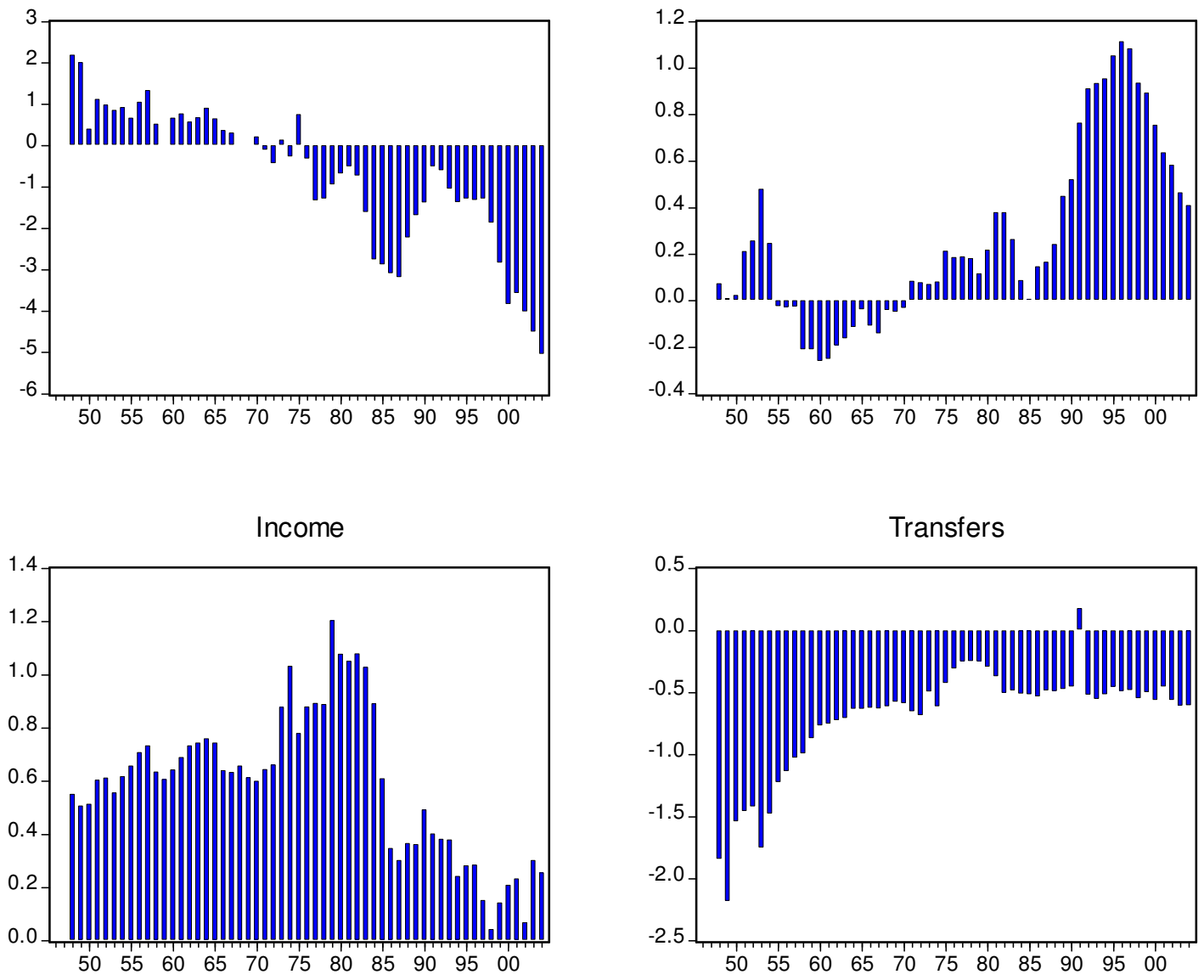

Source: International Transactions, Economic Report of President 2005 
Figure 3: U.S. Net International Investment Position, 1976-2004

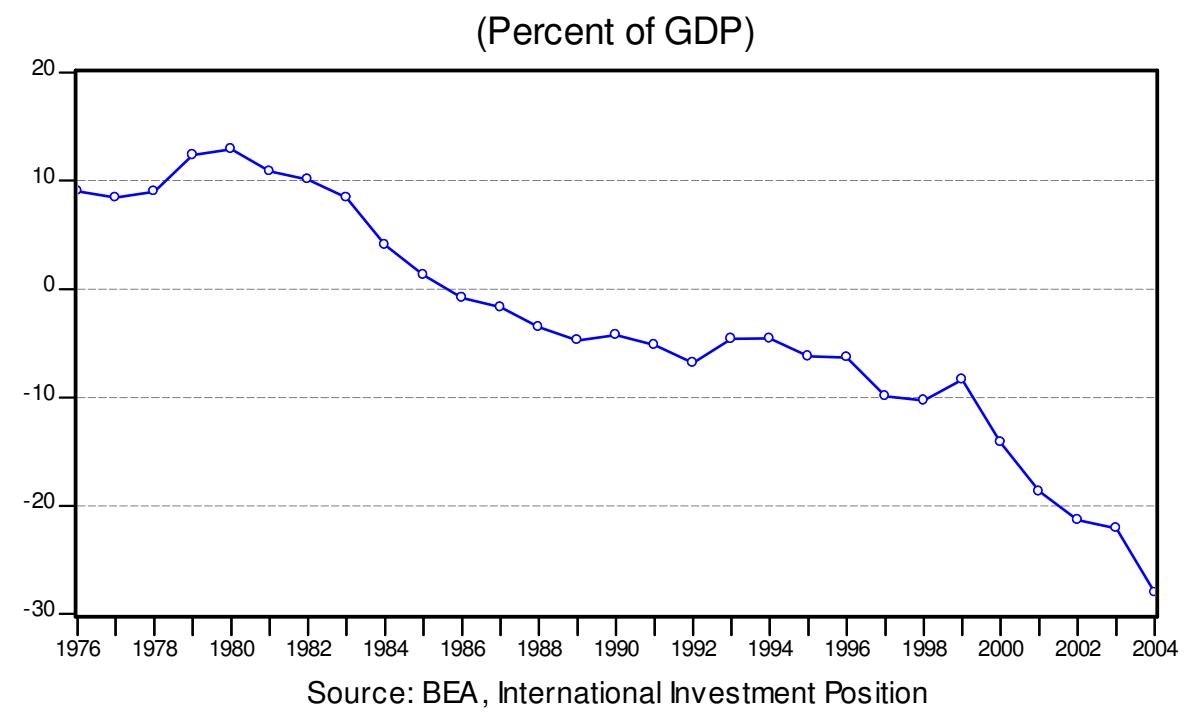

Figure 4: U.S. Investment and Savings, 1970-2003

(Percent of GDP)

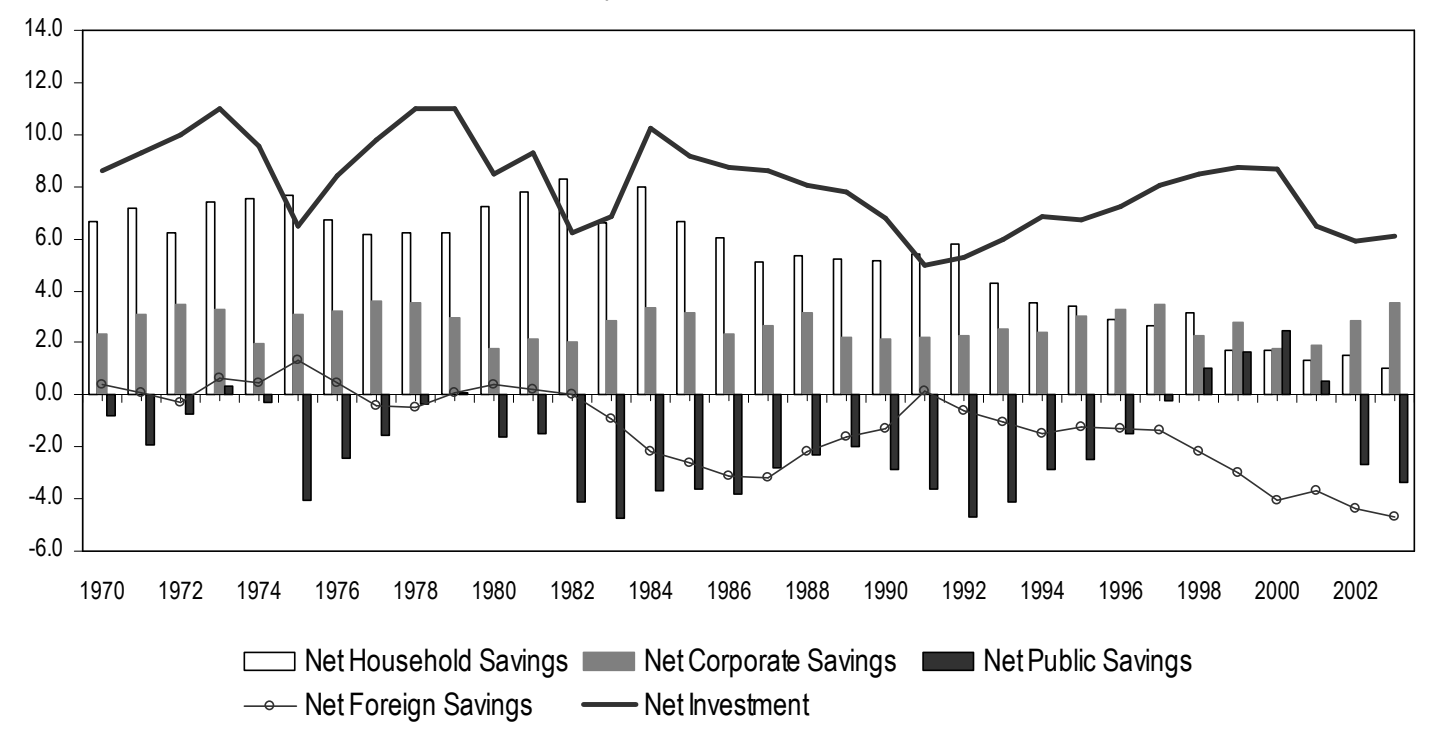

Source: BEA, U.S. International Transactions 
Figure 5: Base Case Simulation Results

Figure 5.A

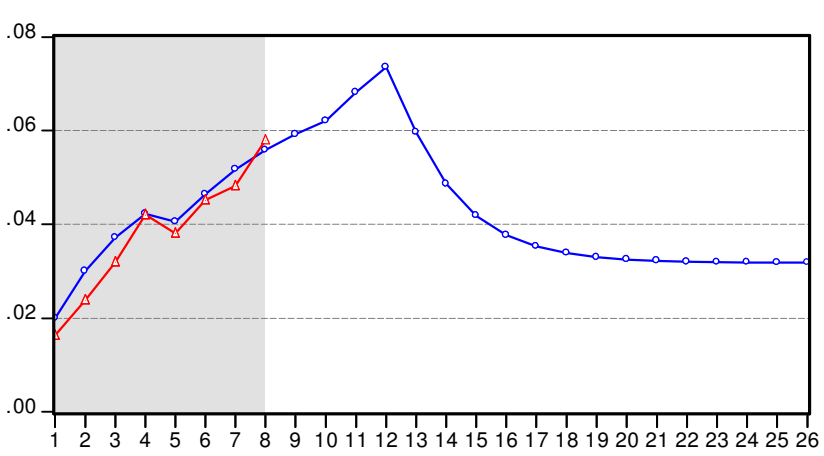

$\multimap$ Current Account Deficit to GDP

$\neg-$ Actual Current Account Deficit to GDP

Figure 5.C

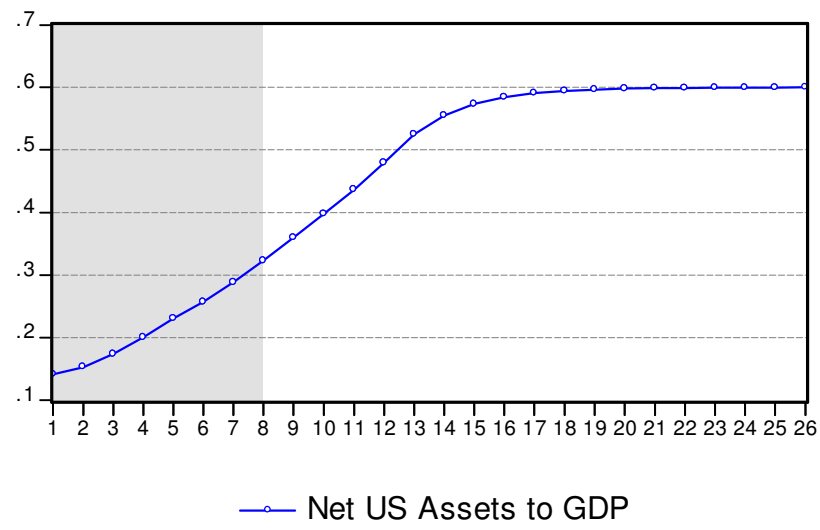

Figure 5.B

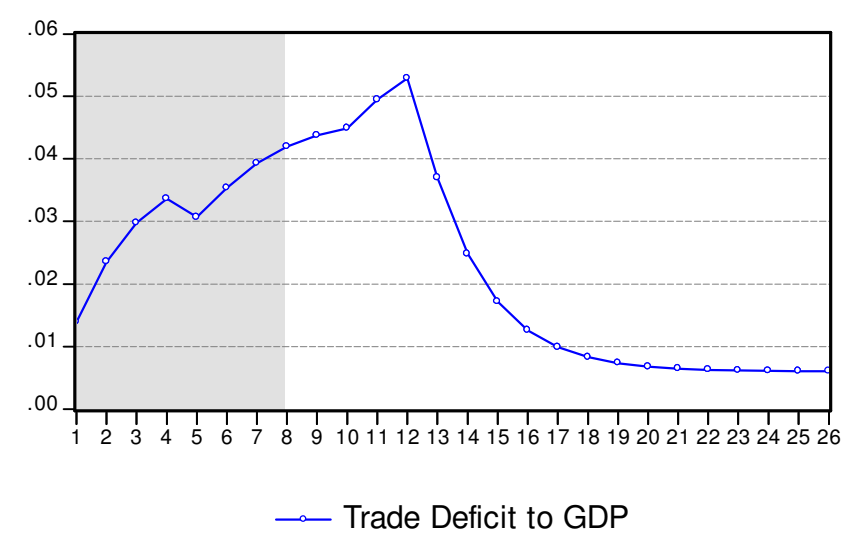

Figure 5.D

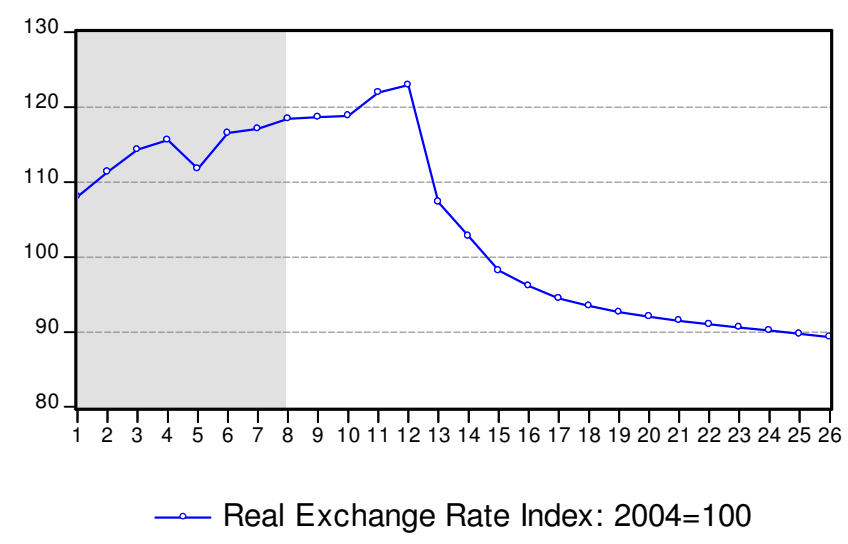


Figure 6: Simulation B Results

(Alternative Assumptions)

Figure 6.A

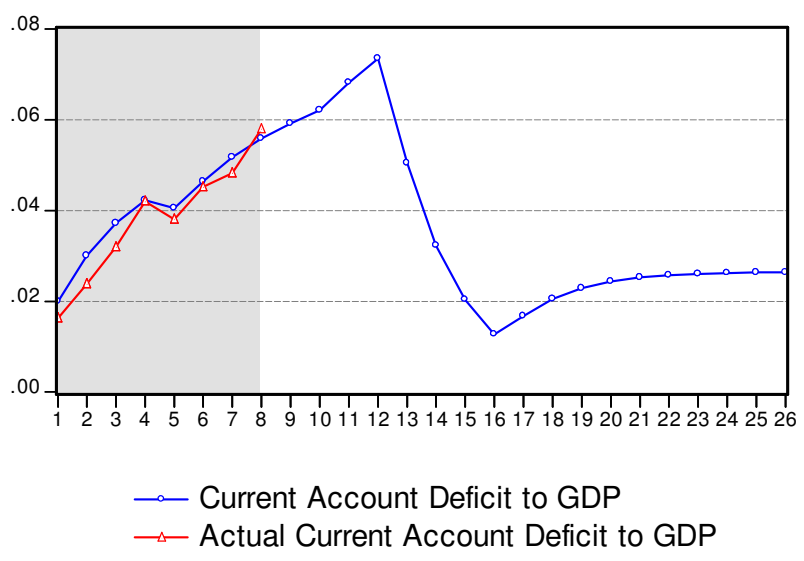

Figure 6.C

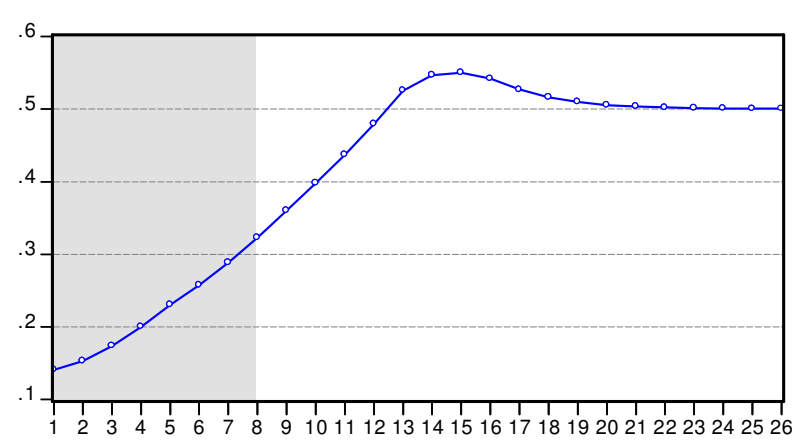

$\multimap$ Net US Assets to GDP
Figure 6.B

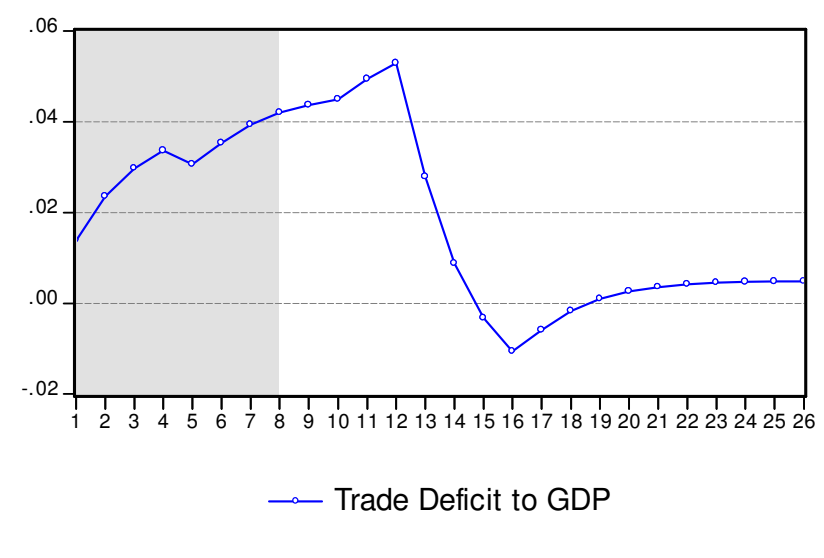

Figure 6.D

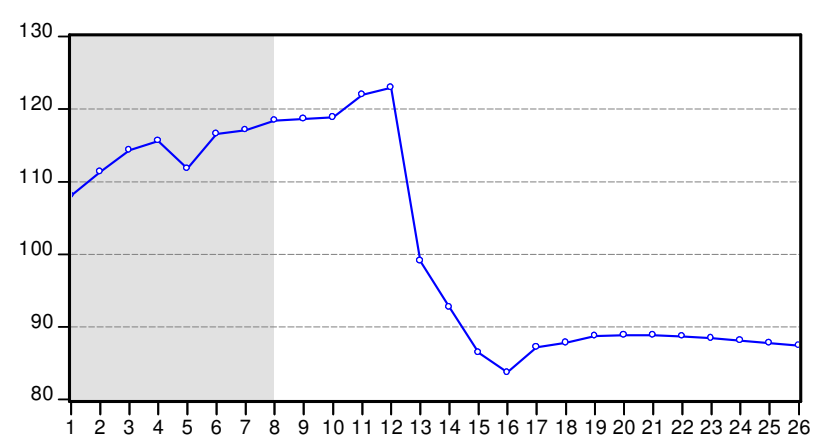

$\multimap$ Real Exchange Rate Index: 2004=100 
Table 1

U.S. Net Financial Flows: 1990-2004

(\$ Billion)

\begin{tabular}{|c|c|c|c|c|c|c|c|c|c|c|c|c|c|c|c|}
\hline & 1990 & 1991 & 1992 & 1993 & 1994 & 1995 & 1996 & 1997 & 1998 & 1999 & 2000 & 2001 & 2002 & 2003 & 2004 \\
\hline Reserves (net) & 31.8 & 23.2 & 44.4 & 70.4 & 44.9 & 100.1 & 133.4 & 18.0 & -26.7 & 52.3 & 42.5 & 23.1 & 110.3 & 250.1 & 358.1 \\
\hline $\begin{array}{l}\text { Foreign private purchases } \\
\text { of U.S. treasuries }\end{array}$ & -2.5 & 18.8 & 37.1 & 24.4 & 34.3 & 91.5 & 147.0 & 130.4 & 28.6 & -44.5 & -70.0 & -14.4 & 100.4 & 113.4 & 108.1 \\
\hline Currency & 18.8 & 15.4 & 13.4 & 18.9 & 23.4 & 12.3 & 17.4 & 24.8 & 16.6 & 22.4 & 5.3 & 23.8 & 21.5 & 16.6 & 14.8 \\
\hline Securities (net) & -27.2 & -10.5 & -19.1 & -66.2 & -6.2 & -45.1 & -46.0 & 44.6 & 32.1 & 182.6 & 338.0 & 309.2 & 301.4 & 178.6 & 323.2 \\
\hline Debt securities & - & - & - & - & - & - & 13.0 & 84.2 & 145.5 & 104.2 & 267.7 & 300.3 & 269.8 & 241.8 & 360.1 \\
\hline Equity securities & - & - & - & - & - & - & -36.8 & 24.7 & -30.3 & 84.5 & 93.0 & 12.6 & 37.5 & -63.2 & -36.8 \\
\hline FDI (net) & 11.3 & -14.7 & -28.4 & -32.6 & -34.0 & -41.0 & -5.4 & 0.8 & 36.4 & 64.5 & 162.1 & 24.7 & -62.4 & -133.9 & -133.0 \\
\hline $\begin{array}{l}\text { Claims reported by non-banks } \\
\text { (net) }\end{array}$ & 17.3 & 8.0 & 13.2 & 11.3 & -35.0 & 14.4 & -32.6 & -5.2 & -15.1 & -21.5 & 31.9 & 57.6 & 32.6 & 55.1 & -41.5 \\
\hline Claims reported by banks (net) & 8.6 & 3.4 & 37.4 & 55.7 & 100.1 & -44.9 & -75.1 & 7.9 & 4.2 & -22.0 & -31.7 & -7.5 & 66.1 & 65.2 & -15.6 \\
\hline Net financing & 58.0 & 43.5 & 97.9 & 81.8 & 127.4 & 87.3 & 138.7 & 221.3 & 76.2 & 233.8 & 478.0 & 416.6 & 569.9 & 542.7 & 614.0 \\
\hline Current account deficit & 79.0 & -3.7 & 48.0 & 82.0 & 118.0 & 109.5 & 120.2 & 136.0 & 209.6 & 296.8 & 413.4 & 385.7 & 473.9 & 530.7 & 665.9 \\
\hline
\end{tabular}

Source: BEA, U.S. International Transactions and International Investment Position 
Table 2

U.S. Net International Investment Position and Current Account Deficit: 1998-2004 (\$ Billion)

\begin{tabular}{l|ccccccc}
\hline & $\mathbf{1 9 9 8}$ & $\mathbf{1 9 9 9}$ & $\mathbf{2 0 0 0}$ & $\mathbf{2 0 0 1}$ & $\mathbf{2 0 0 2}$ & $\mathbf{2 0 0 3}$ & $\mathbf{2 0 0 4}$ \\
\hline NIIP & 900.0 & 775.5 & 1388.7 & 1889.7 & 2233.0 & 2430.7 & -- \\
Change in NIIP & 79.3 & -124.5 & 613.3 & 500.9 & 343.3 & 197.7 & -- \\
Current Account Deficit & 209.5 & 296.8 & 413.4 & 385.7 & 473.9 & 530.7 & 617.7 \\
& & & & & & & \\
Valuation changes & 130.2 & 421.3 & -199.8 & -115.2 & 130.6 & 333.0 & -- \\
\hline
\end{tabular}

Source: Bureau of Economic Analysis

Table 3

Distribution of Current Account Deficits

By Region: 1970-2001

\begin{tabular}{|c|c|c|c|c|c|c|}
\hline Region & Mean & Median & $1^{\text {st } \text { Perc. }}$. & $1^{\text {st }}$ Quartile & $3^{\text {rd }}$ Quartile & $9^{\text {th }}$ Perc. \\
\hline & \multicolumn{6}{|c|}{$\underline{A: 1970-2001}$} \\
\hline Industrialized countries & 0.6 & 0.7 & -3.8 & -1.6 & 3.0 & 4.8 \\
\hline Latin Am. and Caribbean & 5.4 & 4.1 & -2.5 & 1.1 & 8.0 & 16.9 \\
\hline Asia & 3.0 & 2.7 & -7.1 & -0.6 & 6.3 & 11.3 \\
\hline Africa & 6.3 & 5.3 & -3.4 & 1.2 & 9.9 & 16.9 \\
\hline Middle East & 0.0 & 1.4 & -18.8 & -5.0 & 6.4 & 13.6 \\
\hline Eastern Europe & 3.9 & 3.0 & -2.4 & 0.3 & 6.1 & 10.7 \\
\hline \multirow[t]{2}{*}{ Total } & 3.9 & 3.3 & -5.0 & -0.1 & 7.1 & 13.1 \\
\hline & \multicolumn{6}{|c|}{$\underline{A: 1984-2001}$} \\
\hline Industrialized countries & 0.2 & 0.3 & -4.7 & -2.3 & 2.7 & 4.8 \\
\hline Latin Am. and Caribbean & 5.1 & 3.7 & -2.5 & 1.1 & 7.0 & 17.0 \\
\hline Asia & 2.2 & 2.4 & -8.0 & -1.3 & 5.9 & 10.2 \\
\hline Africa & 5.9 & 4.6 & -3.5 & 0.9 & 9.1 & 16.2 \\
\hline Middle East & 2.3 & 1.5 & -12.4 & -4.0 & 6.3 & 14.9 \\
\hline Eastern Europe & 4.0 & 3.1 & -2.5 & 0.3 & 6.6 & 10.9 \\
\hline Total & 3.8 & 3.0 & -4.8 & -0.4 & 6.7 & 12.9 \\
\hline
\end{tabular}

Source: Author's elaboration based on World Development Indicators 
Table 4

List of Countries with Persistent High Current Account Deficits

By Region: 1970-2001

\begin{tabular}{l|c}
\hline Region/ Country & Period \\
\hline Industrialized Countries & \\
\hline Ireland & $1978-1984$ \\
New Zealand & $1984-1988$ \\
$\underline{\text { Latin America and Caribbean }}$ & $1979-1985$ \\
Guyana & $1984-1990 \& 1992-2000$ \\
Nicaragua & $1982-1989$ \\
Bsia & \\
$\underline{\text { Africa }}$ & $1982-1993$ \\
Guinea-Bissau & $1995-2000$ \\
Lesotho & \\
$\underline{\text { Eastern Europe }}$ & $1995-1999$ \\
\hline Azerbaijan & \\
\hline
\end{tabular}

Source: Author's elaboration based on World Development Indicators

Table 5

Net Sock of Liabilities: U.S and other Industrial Countries: Selected Years (Percent of GDP)

\begin{tabular}{l|cccccc}
\hline & 1980 & 1985 & 1990 & 1995 & 2000 & 2003 \\
\hline Australia & -- & -- & 47.4 & 55.1 & 65.2 & 59.1 \\
Canada & 34.7 & 36.3 & 38.0 & 42.4 & 30.6 & 20.6 \\
Denmark & -- & -- & -- & 26.5 & 21.5 & 13.0 \\
Finland & 14.6 & 19.0 & 29.2 & 42.3 & 58.2 & 35.9 \\
Iceland & -- & -- & 48.2 & 49.8 & 55.5 & 66.0 \\
New Zealand & -- & -- & 88.7 & 76.6 & 120.8 & 131.0 \\
Sweden & -- & 20.9 & 26.6 & 41.9 & 36.7 & 26.5 \\
United States & -12.9 & -1.3 & 4.2 & 6.2 & 14.1 & 22.1 \\
\hline
\end{tabular}

Source: Bureau of Economic Analysis and Lane and Milesi-Ferretti (2001). 
Table 6

U.S. Current Account Adjustment and the U.S. Dollar:

Selected Studies, 1999-2005

\begin{tabular}{|c|c|c|c|}
\hline AUTHORS & METHODOLOGY & MAIN ASSUMPTIONS & MAIN RESULTS \\
\hline Mann (1999) & $\begin{array}{l}\text { - Model tracks U.S. NIIP through } \\
\text { time. } \\
\text { - Analyzes trajectory of NIIP under } \\
\text { three scenarios, and asks whether } \\
\text { these trajectories are sustainable. } \\
\text { - Elasticities-based adjustment } \\
\text { mechanism. } \\
\text { - Considers two scenarios for global } \\
\text { growth. }\end{array}$ & $\begin{array}{l}\text { - Income elasticity of imports (1.7) } \\
\text { exceeds income elasticity of exports } \\
(1.0) \text {. } \\
\text { - Base case scenario assumes no RER } \\
\text { adjustment for the USD. } \\
\text { - A USD adjustment scenario } \\
\text { assumes a RER depreciation of } 25 \% \text {. } \\
\text { - A structural adjustment scenario } \\
\text { assumes that exports' elasticity } \\
\text { increases to } 1.3 \text {. }\end{array}$ & $\begin{array}{l}\text { - In base case scenario the NIIP } \\
\text { becomes increasingly negative and } \\
\text { the CA is unsustainable in the } \\
\text { medium run. } \\
\text { - Under RER depreciation scenario } \\
\text { CA is within sustainable ranges even } \\
\text { in a } 10 \text { year long horizon. } \\
\text { - Under structural adjustment, CA } \\
\text { deficit is } 3 \% \text { in a } 10 \text { year horizon, if } \\
\text { the global economy has high } \\
\text { performance. }\end{array}$ \\
\hline Obstfeld and Rogoff (2000) & $\begin{array}{l}\text { - Develops and calibrates optimizing } \\
\text { model of small open economy, with } \\
\text { two goods: tradable and nontradable. } \\
\text { - Output is exogenous; prices are } \\
\text { assumed to be flexible; monetary } \\
\text { policy stabilizes the price level. } \\
\text { - Analyzes the effect on RER of an } \\
\text { exogenous shock that results in a } \\
\text { reduction of the CA deficit of } 4.4 \% \text { of } \\
\text { GDP. }\end{array}$ & $\begin{array}{l}\text { - Elasticity of substitution between } \\
\text { tradables and nontradables is assumed } \\
\text { to be equal to one. } \\
\text { - Assumes a } 6 \% \text { nominal interest rate, } \\
\text { and a NIIP of } 20 \% \text { of GDP. } \\
\text { - Tradables output is assumed to be } \\
25 \% \text { of GDP. } \\
\text { - Assumes that full-employment is } \\
\text { maintained. }\end{array}$ & $\begin{array}{l}\text { - Base case result indicates that an } \\
\text { elimination of the CA deficit will } \\
\text { imply a } 16 \% \text { RER depreciation, and a } \\
12 \% \text { nominal depreciation of the } \\
\text { USD. } \\
\text { - Assuming a share of tradables equal } \\
\text { to } 15 \% \text {, results in a RER depreciation } \\
\text { of } 20 \% \text {. } \\
\text { - The effect on the nominal value of } \\
\text { the USD could be even higher if the } \\
\text { reduction in the CA is very rapid. }\end{array}$ \\
\hline
\end{tabular}




\begin{tabular}{|c|c|c|c|}
\hline AUTHORS & METHODOLOGY & MAIN ASSUMPTIONS & MAIN RESULTS \\
\hline O’Neill and Hatzious (2002) & $\begin{array}{l}\text { - Analyzes the trajectory of NIIP as a } \\
\text { percentage of GDP. } \\
\text { - Argues that at the observed levels of } \\
\text { CA deficits, the NIIP is moving } \\
\text { towards the levels of Canada, } \\
\text { Australia and New Zealand. It is } \\
\text { difficult to believe that this is possible } \\
\text { for a large country such as the U.S. } \\
\text { - Estimates "required" RER } \\
\text { depreciation in order to bring CA } \\
\text { deficit to } 2 \% \text { and NIIP not to surpass } \\
40 \% \text {. }\end{array}$ & $\begin{array}{l}\text { - Analyzes the rates of return obtained } \\
\text { by foreign owners of U.S. assets. } \\
\text { - Argues that with the exception of } \\
\text { FDI these rates of return have been } \\
\text { modest. } \\
\text { - Shows that FDI has declined } \\
\text { significantly as a source of financing } \\
\text { of the U.S. CA deficit. }\end{array}$ & $\begin{array}{l}\text { - It is unlikely that U.S. will be able to } \\
\text { continue to attract foreign purchasing } \\
\text { for its assets at observed low rates of } \\
\text { return. Thus, the U.S. CA deficit is } \\
\text { clearly unsustainable. } \\
\text { - A return to sustainability would ) } 2 \% \\
\text { CA deficit) will imply a depreciation } \\
\text { of the RER of as much as } 43 \% \text {. }\end{array}$ \\
\hline Wren-Lewis (2004) & $\begin{array}{l}\text { - Calibrates a partial equilibrium } \\
\text { model to obtain set of bilateral RER } \\
\text { consistent with attaining certain } \\
\text { (exogenous) current account deficits. } \\
\text { - No attempt is made to determine } \\
\text { what is the sustainable level of the } \\
\text { U.S. current account. } \\
\text { - Considers the effect of a U.S. fiscal } \\
\text { shock and of a U.S. technological } \\
\text { shock. }\end{array}$ & $\begin{array}{l}\text { - To determine initial conditions, } \\
\text { author estimates "underlying" (or } \\
\text { cycle-adjusted) CA balances. } \\
\text { - Considers } 3 \text { possible long term } \\
\text { scenarios: } 1 \%, 2 \% \text { and } 3 \% \text { CA deficit. } \\
\text { - Three-good partial equilibrium } \\
\text { model (including a nontraded) of } \\
\text { small economy. } \\
\text { - Elasticities and other parameter } \\
\text { values taken from regression analysis } \\
\text { and from OECD data set. }\end{array}$ & $\begin{array}{l}\text { - CA deficit of } 2 \% \text { of GDP is } \\
\text { consistent with a yen/dollar rate of } 88 \text {, } \\
\text { and a dollar/euro of } 1.18 \text {. } \\
\text { - If there is a positive technological } \\
\text { shock, the "sustainable" CA deficit } \\
\text { may be higher. This would be } \\
\text { consistent a yen/dollar rate of } 89-100 \text {, } \\
\text { and a dollar/euro of } 1.11-1.19 \text {. } \\
\text { - Estimates that if China has a CA } \\
\text { surplus of } 1 \% \text { of GDP the Rmb/USD } \\
\text { would be } 6.71 .\end{array}$ \\
\hline
\end{tabular}




\begin{tabular}{|c|c|c|c|}
\hline AUTHORS & METHODOLOGY & MAIN ASSUMPTIONS & MAIN RESULTS \\
\hline Benassy-Quere et al (2004) & $\begin{array}{l}\text { - Estimates econometrically RER path } \\
\text { consistent with nontradable } \\
\text { equilibrium. } \\
\text { - The RER is assumed to depend on } \\
\text { the country's net foreign assets (NFA) } \\
\text { position and on relative productivity. }\end{array}$ & $\begin{array}{l}\text { - Model estimated simultaneously for } \\
15 \text { currencies. } \\
\text { - Data on NFA obtained from lane } \\
\text { and Milessi-Ferreti (2004) and } \\
\text { relative productivities obtained as } \\
\text { ratio of CPI to PPI. } \\
\text { - No attempt is made to impose } \\
\text { external equilibrium condition. } \\
\text { - Rsults provided for two cases: USD } \\
\text { as numeraire and euro as numeraire. }\end{array}$ & $\begin{array}{l}\text { - The extent of misalignment of the } \\
\text { different currencies depends on how } \\
\text { broad is the adjustment. } \\
\text { - Using the USD as numeraire, } \\
\text { estimates that in } 2003 \text { the euro was } \\
\text { undervalued between } 1.2 \% \text { and } 7.6 \% \text {. } \\
\text { - Using the USD as numeraire, } \\
\text { estimates that in } 2001 \text { the yen was } \\
\text { undervalued between } 14.3 \% \text { and } \\
22.1 \% \text {. }\end{array}$ \\
\hline Mussa (2004) & $\begin{array}{l}\text { - Analyzes trajectory of NIIP and } \\
\text { argues that it is unlikely that it will } \\
\text { continue to grow at current pace. If it } \\
\text { did it would reach } 100 \% \text { of GDP. } \\
\text { - Argues that challenge is for RER } \\
\text { adjustment to be gradual and that it } \\
\text { does not disrupt growth. } \\
\text { - Argues that fiscal adjustment in the } \\
\text { U.S. is necessary for smooth } \\
\text { correction of imbalances. } \\
\text { - No attempt is made at calculating } \\
\text { the "outer limit" of U.S. NIIP. } \\
\text { - Analyzes the RER adjustment } \\
\text { compatible with a gradual reduction } \\
\text { of the CA deficit to } 2 \% \text { of GDP and a } \\
\text { NIIP between } 40 \% \text { and } 50 \% \text {. }\end{array}$ & $\begin{array}{l}\text { - Based on results from large } \\
\text { econometric models assumes that a } \\
1 \% \text { reduction of the U.S. CA deficit is } \\
\text { associated with a } 10 \% \text { depreciation of } \\
\text { the RER. }\end{array}$ & $\begin{array}{l}\text { - Relative to its value in mid } 2004 \text {, } \\
\text { Mussa calculates that the RER will } \\
\text { have to depreciate another } 20 \% \text { to } \\
\text { achieve a long term CA deficit of } 2 \% \text {. } \\
\text { - Discusses policies that will assist the } \\
\text { adjustment process: (a) Fiscal } \\
\text { consolidation in the U.S. will help } \\
\text { keep U.S. demand growing below the } \\
\text { pace of output growth. (b) Monetary } \\
\text { policy in Europe and Japan should be } \\
\text { more expansive. } \\
\text { - Concludes that "some" international } \\
\text { policy cooperation is likely to help the } \\
\text { adjustment process. }\end{array}$ \\
\hline
\end{tabular}




\begin{tabular}{|c|c|c|c|}
\hline AUTHORS & METHODOLOGY & MAIN ASSUMPTIONS & MAIN RESULTS \\
\hline O'Neill and Hatzious (2004) & $\begin{array}{l}\text { - Update of O'Neill and Hatzious } \\
(2002) \text { model. } \\
\text { - Analyzes the trajectory of NIIP as a } \\
\text { percentage of GDP, and finds that } \\
\text { path is not sustainabl. } \\
\text { - Introduces the role of productivity } \\
\text { gains to original framework. } \\
\text { - Analyzes the composition of capital } \\
\text { flows into the U.S. } \\
\text { - Incorporates the role of valuation } \\
\text { effects. }\end{array}$ & $\begin{array}{l}\text { - Estimates a trade balance equation } \\
\text { and uses the coefficients to compute } \\
\text { the "required" RER depreciation to } \\
\text { achieve different CA adjustment } \\
\text { targets. } \\
\text { - Trade equation also includes foreign } \\
\text { and U.S. demand growth. }\end{array}$ & $\begin{array}{l}\text { - A reduction of the CA deficit to } 3 \% \\
\text { would imply RER depreciation of the } \\
\text { order of } 21.6 \% \text { to } 23.6 \% \text {. } \\
\text { - A reduction of the CA deficit to } 2 \% \\
\text { would imply RER depreciation of the } \\
\text { order of } 32.1 \% \text { to } 34.1 \% \text {. } \\
\text { - An elimination of the CA deficit to } \\
2 \% \text { would imply RER depreciation of } \\
\text { the order of } 53 \% \text { to } 55 \% \text {. (Notice that } \\
\text { these figures are significantly higher } \\
\text { than those estimated by Obstfeld and } \\
\text { Rogoff, 2004). }\end{array}$ \\
\hline Obstfeld and Rogoff (2004) & $\begin{array}{l}\text { - Extension of the Obstfeld-Rogoff } \\
\text { (2002) model to a two-country world. } \\
\text { - Terms of trade are now endogenous. } \\
\text { - Incorporates the effects of valuation } \\
\text { effects of exchange rate changes on } \\
\text { NIIP. } \\
\text { - Exercise assumes an elimination of } \\
\text { the CA deficit; that is a reduction in } \\
5 \% \text { of GDP. }\end{array}$ & $\begin{array}{l}\text { - Ratio of CA deficit to tradables is } \\
25 \% \text {; CA deficit is } 5 \% \text { of GDP. } \\
\text { - Output is exogenously given in both } \\
\text { countries. } \\
\text { - NIIP is } 20 \% \text { of GDP. } \\
\text { - Home country produces } 22 \% \text { of } \\
\text { world tradables. } \\
\text { - Simulation is done for alternative } \\
\text { values of elasticities, and under } \\
\text { different assumptions regarding } \\
\text { changes in tradables output and } \\
\text { military spending. }\end{array}$ & $\begin{array}{l}\text { - Assuming constant output, an } \\
\text { elimination of the CA deficit implies } \\
\text { RER depreciation between } 14.7 \% \text { and } \\
33.6 \% \text {. } \\
\text { - If tradables output increases by } \\
20 \% \text {, the RER depreciation ranges } \\
\text { from } 9.8 \% \text { to } 22.5 \% \text {. } \\
\text { - If there is a permanent increase in } \\
\text { military expenditure,the RER } \\
\text { depreciation ranges from } 16.0 \% \text { to } \\
36.1 \% \text {. }\end{array}$ \\
\hline
\end{tabular}




\begin{tabular}{|c|c|c|c|}
\hline AUTHORS & METHODOLOGY & MAIN ASSUMPTIONS & MAIN RESULTS \\
\hline Roubini and Setser (2004) & $\begin{array}{l}\text { - Uses macro aggregate model to } \\
\text { project the U.S. current account. } \\
\text { - Imposes exogenous assumptions on } \\
\text { RER, and analyzes CA path }\end{array}$ & $\begin{array}{l}\text {-First scenario considers a constant } \\
\text { RER dollar. } \\
\text {-Second scenario considers a constant } \\
\text { trade deficit at } 5 \% \text { of GDP, and a } \\
\text { RER depreciation of approximately } \\
7 \% \text {. } \\
\text { - Third scenario considers a faster rate } \\
\text { of growth of exports, and substantial } \\
\text { (50\%) depreciation. This scenario } \\
\text { also assumes a gradual elimination } \\
\text { (by 2012) of the fiscal deficit. }\end{array}$ & $\begin{array}{l}\text {-In first scenario, CA deficit } 13 \% \text { of } \\
\text { GDP in } 2012 . \\
\text {-In second scenario, CA deficit } 9 \% \text { of } \\
\text { GDP in } 2012 \text {. } \\
\text {-In third scenario, the NIIP stabilizes } \\
\text { at approximately } 55 \% \text { of GDP, and } \\
\text { the CA deficit declines gradually, } \\
\text { reaching } 4.3 \% \text { of GDP in } 2012 \text {. }\end{array}$ \\
\hline Blanchard, Giavazzi, Sa (2005) & $\begin{array}{l}\text { - Uses portfolio model to analyze } \\
\text { U.S. current account behavior. } \\
\text { - Assumes changes in portfolio } \\
\text { preferences in world economy. }\end{array}$ & $\begin{array}{l}\text { - Considers dynamics of adjustment. } \\
\text { - Considers valuation effects of } \\
\text { changes in the U.S. dollar. } \\
\text { - Simulates model under certain } \\
\text { assumptions for values of key } \\
\text { parameters (elasticities, portfolio } \\
\text { shares and other). } \\
\text { - The question asked is: what is the } \\
\text { required (real) depreciation of the } \\
\text { U.S. dollar to eliminate the current } \\
\text { account deficit? }\end{array}$ & $\begin{array}{l}\text { - Estimates range of required U.S. } \\
\text { dollar real depreciation (today). After } \\
\text { incorporating the role of valuation } \\
\text { effects the range is estimated to be } \\
\text { between } 40 \% \text { and } 90 \% \text { real } \\
\text { depreciation. }\end{array}$ \\
\hline
\end{tabular}


Table 7

Simulation Parameters

\begin{tabular}{|c|c|c|}
\hline Variables & Parameter Values & $\frac{\text { Comments and Values in Alternative }}{\text { Simulations }}$ \\
\hline \multicolumn{3}{|c|}{ A. Portfolio Adjustment } \\
\hline$W_{\text {Initial }}^{\text {Word }}$ & USD 80 Trillion & World wealth in U.S. dollars in 2005. \\
\hline$W_{\text {Initial }}^{U S}$ & USD 36 Trillion & U.S. wealth in U.S. dollars in 2005. \\
\hline$\alpha_{\text {Initial }}$ & 0.300 & $\begin{array}{l}\text { Foreigners' demand for U.S. assets in } \\
\text { (early) } 2005 .\end{array}$ \\
\hline$\overline{\alpha_{j j, \text { Initial }}}$ & 0.730 & $\begin{array}{l}\text { U.S. residents' demand for U.S. assets in } \\
\text { (early) } 2005 \text {. }\end{array}$ \\
\hline$\alpha_{\text {Final }}$ & 0.400 & $\begin{array}{l}\text { Foreigners' portfolio allocation for U.S. } \\
\text { assets in } 2010 \text {. In Simulation } B \text { I assume } \\
\text { that after reaching } 0.40 \alpha \text { declines } \\
\text { gradually to } 0.365 \text {. It reaches this new } \\
\text { value in } 2014 \text {. }\end{array}$ \\
\hline$\alpha_{j j, \text { Final }}$ & 0.710 & $\begin{array}{l}\text { U.S. residents' demand for U.S. assets in } \\
\text { (early) } 2010 \text {. In Simulation B I assume that } \\
\text { after reaching } 0.71 \alpha_{i j} \text { changes to } 0.72 \text { as a } \\
\text { final value in } 2014 \text {. }\end{array}$ \\
\hline$\alpha_{\text {Historical }}$ & 0.205 & $\begin{array}{l}\text { Foreigners' demand for U.S. assets in } \\
\text { (early) 1996. Move to current } 0.30 \text { is } \\
\text { assumed to have been gradual. }\end{array}$ \\
\hline$\alpha_{j j, \text { Historical }}$ & 0.800 & $\begin{array}{l}\text { U.S. residents' demand for U.S. assets in } \\
\text { (early) } 1996 .\end{array}$ \\
\hline$\lambda$ & 3 & Wealth to GDP ratio. \\
\hline$\gamma_{\text {Initial }}^{*}$ & 0.290 & Gamma in (early) 2005. \\
\hline$\gamma_{\text {Final }}^{*}$ & 0.600 & Final gamma in 2010. \\
\hline$\gamma_{\text {Historical }}^{*}$ & 0.150 & Initial gamma in 1996. \\
\hline $\begin{array}{l}\text { Adjustment period } \\
\text { for } \alpha \text { and } \alpha_{j j}\end{array}$ & Five years & \\
\hline
\end{tabular}


Table 7

Simulation Parameters

(Continuation)

\begin{tabular}{|c|c|c|}
\hline Variables & Parameter Values & $\frac{\text { Comments and Values in Alternative }}{\underline{\text { Simulations }}}$ \\
\hline \multicolumn{3}{|c|}{ B. $\underline{\text { Transfer Problem }}$} \\
\hline$g$ & 0.03 & $\begin{array}{l}\text { Assumed to be the long-term sustainable } \\
\text { rate of growth of U.S. GDP. }\end{array}$ \\
\hline$g^{*}$ & 0.03 & $\begin{array}{l}\text { Rest of the world growth (this includes the } \\
\text { emerging countries as well as Europe and } \\
\text { Japan). }\end{array}$ \\
\hline$\pi$ & 0.023 & Long term U.S. inflation. \\
\hline$\pi^{*}$ & 0.023 & $\begin{array}{l}\text { A slightly higher value ( } 0.03) \text { was used in } \\
\text { some of the simulations. }\end{array}$ \\
\hline$i$ & 0.043 & $\begin{array}{l}\text { Other simulations used a higher value in } \\
\text { the range } 0.05 \text { to } 0.065 \text {. }\end{array}$ \\
\hline$i^{*}$ & 0.053 & $\begin{array}{l}\text { Alternative values in the range } 0.06 \text { to } \\
0.075 \text {. }\end{array}$ \\
\hline$\eta_{e}$ & -1.10 & $\begin{array}{l}\text { This is slightly below the consensus price } \\
\text { elasticity for U.S. imports. Range of } \\
\text { values used in other simulations. }\end{array}$ \\
\hline$\varepsilon_{e}$ & 0.35 & $\begin{array}{l}\text { Approximate consensus value for RER } \\
\text { elasticity of U.S. exports. Sensitivity } \\
\text { analysis used range } 0.2 / 0.6 \text {. }\end{array}$ \\
\hline$\eta_{y}$ & 1.50 & $\begin{array}{l}\text { Consensus value for income elasticity of } \\
\text { U.S. imports. }\end{array}$ \\
\hline$\varepsilon_{y}$ & 1.00 & $\begin{array}{l}\text { Consensus value for income elasticity of } \\
\text { U.S. imports. }\end{array}$ \\
\hline$\sigma_{m}$ & 0.14 & Share of imports in U.S. GDP in 2004. \\
\hline$\sigma_{x}$ & 0.09 & Share of exports in U.S. GDP in 2004. \\
\hline$\hat{p}_{m}^{*}$ & 0 & $\begin{array}{l}\text { In alternative simulations a range of }-.05 \text { to } \\
-.10 \text { was used. }\end{array}$ \\
\hline$\hat{p}_{x}^{*}$ & 0 & $\begin{array}{l}\text { In alternative simulations a range of } .05 \text { to } \\
.07 \text { was used. }\end{array}$ \\
\hline$\psi$ & 0.30 & $\begin{array}{l}\text { Partial adjustment coefficient; value chosen } \\
\text { to obtain best possible fit for 1996-2004 } \\
\text { period. }\end{array}$ \\
\hline$\kappa$ & 0.20 & $\begin{array}{l}\text { Partial adjustment coefficient; value chosen } \\
\text { to obtain best possible fit for 1996-2004 } \\
\text { period. }\end{array}$ \\
\hline
\end{tabular}


Table 8

Incidence of Current Account Reversals: 1970-2001 (Percentages)

\begin{tabular}{|c|c|c|c|c|}
\hline \multirow[t]{2}{*}{ Region } & \multicolumn{2}{|c|}{ Reversal I } & \multicolumn{2}{|c|}{ Reversal II } \\
\hline & No reversal & Reversal & No reversal & Reversal \\
\hline Industrial countries & 97.3 & 2.7 & 98.0 & 2.0 \\
\hline Latin American and Caribbean & 92.0 & 8.0 & 87.7 & 12.3 \\
\hline Asia & 88.3 & 11.7 & 87.7 & 12.3 \\
\hline Africa & 88.3 & 11.7 & 83.4 & 16.6 \\
\hline Middle East & 86.6 & 13.4 & 85.0 & 15.0 \\
\hline Eastern Europe & 90.7 & 9.3 & 88.9 & 11.1 \\
\hline Total & 90.8 & 9.2 & 88.2 & 11.8 \\
\hline Pearson & & & & \\
\hline Uncorrected chi2 (5) & \multicolumn{2}{|c|}{37.31} & \multicolumn{2}{|c|}{67.42} \\
\hline Design-based $F(5,12500)$ & \multicolumn{2}{|c|}{7.46} & \multicolumn{2}{|c|}{13.08} \\
\hline P-value & \multicolumn{2}{|c|}{0.00} & \multicolumn{2}{|c|}{0.00} \\
\hline
\end{tabular}

Source: Author's elaboration based on World Development Indicators 
Table 9

Incidence of Current Account Reversals and Sudden Stops: 1970-2001 (Percentages)

\begin{tabular}{|c|c|c|}
\hline & Reversal I & Reversal II \\
\hline \multicolumn{3}{|c|}{ A. Large Countries } \\
\hline Reversal I Sudden & 9.3 & 25.5 \\
\hline Sudden I Reversal & 7.0 & 15.6 \\
\hline$\chi^{2}(1)$ & 1.3 & 27.5 \\
\hline P-value & 0.26 & 0.00 \\
\hline \multicolumn{3}{|c|}{ B. Industrial Countries } \\
\hline Reversal I Sudden & 5.0 & 18.2 \\
\hline Sudden I Reversal & 7.1 & 28.6 \\
\hline$\chi^{2}(1)$ & 0.4 & 23.6 \\
\hline P-value & 0.51 & 0.00 \\
\hline \multicolumn{3}{|l|}{ C. All Countries } \\
\hline Reversal I Sudden & 21.1 & 51.0 \\
\hline Sudden I Reversal & 15.0 & 26.7 \\
\hline$\chi^{2}(1)$ & 26.6 & 262.5 \\
\hline P-value & 0.00 & 0.00 \\
\hline
\end{tabular}

$\mathrm{xl} y$ denotes the probability of occurrence of $\mathrm{x}$ given the occurrence of $\mathrm{y}$ Source: Author's elaboration based on World Development Indicators 
Table 10

Percentage of Reversals that also Correspond to Currency Crisis

(P-Value of $\chi^{2}$ in parenthesis)

\begin{tabular}{|c|c|c|c|c|c|c|}
\hline & \multicolumn{2}{|c|}{$\begin{array}{l}\text { Contemporaneous } \\
\text { joint occurrence }\end{array}$} & \multicolumn{2}{|c|}{$\begin{array}{c}\text { Crisis lagged one } \\
\text { period }\end{array}$} & \multicolumn{2}{|c|}{$\begin{array}{c}\text { Crisis lagged two } \\
\text { periods }\end{array}$} \\
\hline A. Reversal I & Crisis A & Crisis B & Crisis A & Crisis B & Crisis A & Crisis B \\
\hline Large Countries & $\begin{array}{c}26.7 \\
(0.09)\end{array}$ & $\begin{array}{c}16.1 \\
(0.01)\end{array}$ & $\begin{array}{c}43.1 \\
(0.00)\end{array}$ & $\begin{array}{c}17.2 \\
(0.00)\end{array}$ & $\begin{array}{c}34.5 \\
(0.00)\end{array}$ & $\begin{array}{c}13.8 \\
(0.05)\end{array}$ \\
\hline Industrial Countries & $\begin{array}{c}6.7 \\
(0.49)\end{array}$ & $\begin{array}{c}0.0 \\
(0.43)\end{array}$ & $\begin{array}{c}25.0 \\
(0.16)\end{array}$ & $\begin{array}{c}12.5 \\
(0.10)\end{array}$ & $\begin{array}{c}50.0 \\
(0.00)\end{array}$ & $\begin{array}{c}12.5 \\
(0.11)\end{array}$ \\
\hline All Countries & $\begin{array}{c}21.2 \\
(0.10)\end{array}$ & $\begin{array}{c}9.1 \\
(0.38)\end{array}$ & $\begin{array}{c}25.6 \\
(0.00)\end{array}$ & $\begin{array}{c}10.3 \\
(0.08)\end{array}$ & $\begin{array}{c}22.2 \\
(0.01)\end{array}$ & $\begin{array}{c}9.8 \\
(0.09)\end{array}$ \\
\hline B. Reversal II & & & & & & \\
\hline Large Countries & $\begin{array}{c}31.2 \\
(0.00)\end{array}$ & $\begin{array}{c}18.2 \\
(0.00)\end{array}$ & $\begin{array}{c}42.9 \\
(0.00)\end{array}$ & $\begin{array}{c}15.6 \\
(0.00)\end{array}$ & $\begin{array}{c}29.5 \\
(0.01)\end{array}$ & $\begin{array}{c}12.8 \\
(0.04)\end{array}$ \\
\hline Industrial Countries & $\begin{array}{c}28.6 \\
(0.09\end{array}$ & $\begin{array}{c}14.3 \\
(0.07)\end{array}$ & $\begin{array}{c}35.7 \\
(0.01)\end{array}$ & $\begin{array}{c}0.0 \\
(0.43)\end{array}$ & $\begin{array}{c}26.7 \\
(0.11)\end{array}$ & $\begin{array}{c}6.7 \\
(0.67)\end{array}$ \\
\hline All Countries & $\begin{array}{c}20.2 \\
(0.05\end{array}$ & $\begin{array}{c}10.0 \\
(0.03)\end{array}$ & $\begin{array}{c}23.8 \\
(0.00)\end{array}$ & $\begin{array}{c}11.5 \\
(0.00)\end{array}$ & $\begin{array}{c}16.7 \\
(0.86)\end{array}$ & $\begin{array}{c}8.2 \\
(0.47)\end{array}$ \\
\hline
\end{tabular}

Source: Author's elaboration based on World Development Indicators 
Table 11

Mean Changes in Nominal and Real Exchange Rates: Reversal I

Accumulated change between the year of reversal and three years before

(Percentages)

\begin{tabular}{|c|c|c|c|}
\hline & Treatment & Control & $\begin{array}{c}\text { Kruskal-Wallis test } \\
(p \text {-value })^{*}\end{array}$ \\
\hline & \multicolumn{3}{|c|}{$\underline{\text { Nominal Exchange Rate }}$} \\
\hline Large Countries & 33.1 & 9.2 & 0.00 \\
\hline Industrial Countries & 18.9 & 3.2 & 0.19 \\
\hline \multirow[t]{2}{*}{ All Countries } & 27.5 & 9.5 & 0.00 \\
\hline & \multicolumn{3}{|c|}{$\underline{\text { Real Exchange Rate }}^{* *}$} \\
\hline Large Countries & 1.4 & 0.04 & 0.12 \\
\hline Industrial Countries & 9.3 & 1.6 & 0.55 \\
\hline All Countries & -4.0 & 3.6 & 0.00 \\
\hline
\end{tabular}

* Null Hypothesis: Data from treatment and control countries have been drawn from the same population.

** A positive number means real exchange rate appreciation. 


\section{Table 12}

\section{Current Account Reversals: Random Effects Probit Model - Unbalanced Panel}

\section{Large Countries}

\begin{tabular}{|c|c|c|c|c|}
\hline Variable & $(\mathbf{1 2 . 1})$ & (12.2) & $(\mathbf{1 2 . 3 )}$ & $(\mathbf{1 2 . 4 )}$ \\
\hline & \multicolumn{2}{|c|}{$\underline{\text { Reversal I }}$} & \multicolumn{2}{|c|}{$\underline{\text { Reversal II }}$} \\
\hline \multirow[t]{2}{*}{ Current-Account deficit to GDP } & 0.05 & 0.05 & 0.19 & 0.19 \\
\hline & $(1.65)^{* * *}$ & $(1.63)^{* * *}$ & $(5.46)^{*}$ & $(5.53)^{*}$ \\
\hline \multirow[t]{2}{*}{ Sudden stop } & 0.82 & 0.83 & 0.93 & 0.83 \\
\hline & $(2.06)^{* *}$ & $(2.08)^{* *}$ & $(2.46)^{* *}$ & $(2.24)^{* *}$ \\
\hline \multirow[t]{2}{*}{ Sudden stops in region } & 0.78 & 0.80 & 1.42 & 1.64 \\
\hline & $(0.66)$ & $(0.68)$ & $(1.54)$ & $(1.84) * * *$ \\
\hline \multirow[t]{2}{*}{ External debt to GDP } & 0.01 & 0.01 & 0.001 & 0.001 \\
\hline & $(2.81)^{*}$ & $(2.88)^{*}$ & $(0.29)$ & $(0.32)$ \\
\hline \multirow[t]{2}{*}{ Domestic credit growth } & 0.001 & 0.001 & 0.0002 & 0.0003 \\
\hline & $(2.50) * *$ & $(2.52)^{* *}$ & $(1.65)^{* * *}$ & $(1.71)^{* * *}$ \\
\hline \multirow[t]{2}{*}{ Fiscal deficit to GDP } & -0.004 & - & 0.05 & -- \\
\hline & $(0.12)$ & -- & $(1.85)^{* * *}$ & -- \\
\hline \multirow[t]{2}{*}{ Initial GDP per capita } & -0.28 & -0.29 & -0.15 & -0.16 \\
\hline & $(2.19)^{* *}$ & $(2.23)^{* *}$ & $(1.57)$ & $(1.66)^{* * *}$ \\
\hline Observations & 545 & 582 & 557 & 597 \\
\hline Countries & 36 & 37 & 36 & 37 \\
\hline
\end{tabular}

Absolute value of $z$ statistics are reported in parentheses; explanatory variables are one-period lagged variable; country-specific dummies are included, but not reported.

$*$ significant at $1 \%$; ** significant at $5 \%$; *** significant at $10 \%$ 
Table 13

Current Account Reversals, Sudden Stops and Growth

(Random Effects GLS Estimates)

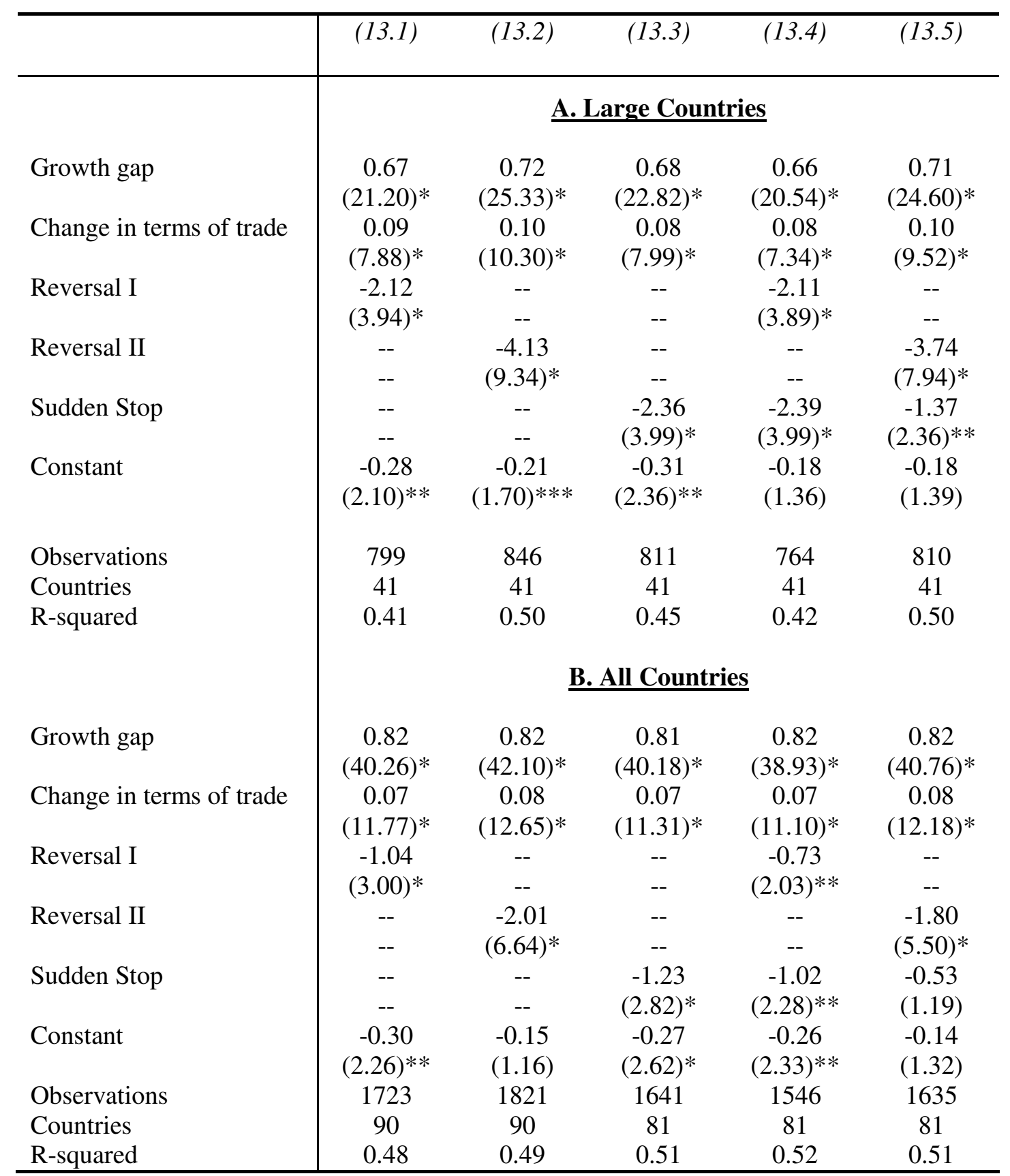

Absolute value of t statistics are reported in parentheses; country-specific dummies are included, but not reported; *significant at $1 \%, * *$ significant at $5 \%, * * *$ significant at $10 \%$. 
Table 14

Current Account Reversals, Sudden Stops and Growth: Trade and Capital Mobility

\section{Large Countries}

(Random Effects GLS Estimates)

\begin{tabular}{l|cc|cc|}
\hline & $(14.1)$ & $(14.2)$ & $(14.3)$ & $(14.4)$ \\
\hline \multirow{4}{*}{ Growth gap } & & & & \\
Change in terms of trade & 0.67 & 0.67 & 0.68 & 0.68 \\
& $(21.17)^{*}$ & $(21.12)^{*}$ & $(22.35)^{*}$ & $(22.40)^{*}$ \\
Reversal I & 0.09 & 0.09 & 0.09 & 0.09 \\
& $(7.78)^{*}$ & $(7.83)^{*}$ & $(8.77)^{*}$ & $(8.79)^{*}$ \\
Reversal I * Trade & -3.48 & -3.84 & -- & -- \\
Reversal I * Capital Mobility & $(1.98)^{* *}$ & $(4.42)^{*}$ & -- & -- \\
& 0.27 & 0.27 & -- & -- \\
Reversal II & $(2.47)^{* *}$ & $(2.55)^{* *}$ & -- & -- \\
Reversal II * Trade & -0.007 & -- & -- & -- \\
Reversal II * Capital Mobility & $(0.24)$ & -- & -- & -- \\
Constant & -- & -- & -1.92 & -4.12 \\
Observations & -- & -- & $(1.38)$ & $(7.94)^{*}$ \\
Countries & -- & -- & -0.02 & -0.04 \\
R-squared & -- & -- & $(0.58)$ & $(1.27)$ \\
& -- & -- & -0.05 & -- \\
\hline
\end{tabular}

Absolute value of $\mathrm{t}$ statistics are reported in parentheses; country-specific dummies are included, but not reported.

*significant at $1 \%, * *$ significant at $5 \%, * * *$ significant at $10 \%$ 


\section{Table 15}

Current Account Reversals, Sudden Stops and Growth: Large Countries

(IV Estimates)

\begin{tabular}{l|cc}
\hline & $(15.1)$ & $(15.2)$ \\
\hline & & \\
Growth gap & 0.86 & 0.89 \\
Change in terms of trade & $(18.50)^{*}$ & $(20.50)^{*}$ \\
& 0.06 & 0.11 \\
Reversal I & $(3.87)^{*}$ & $(6.86)^{*}$ \\
& -9.40 & -- \\
Reversal II & $(4.55)^{*}$ & -- \\
& -- & -12.24 \\
Constant & -- & $(7.40)^{*}$ \\
& 0.24 & 0.38 \\
Observations & $(1.27)$ & $(1.95)^{* * *}$ \\
Countries & 514 & 538 \\
R-squared & 34 & 34 \\
& 0.41 & 0.40 \\
\hline
\end{tabular}

Absolute value of $t$ statistics are reported in parentheses; country-specific dummies are included, but not reported.

*significant at $1 \%, * *$ significant at $5 \%, * * *$ significant at $10 \%$ 
Appendix

Description of the Data

\begin{tabular}{|c|c|c|}
\hline Variable & Definition & Source \\
\hline $\begin{array}{l}\text { Current-Account } \\
\text { Reversal I }\end{array}$ & $\begin{array}{l}\text { Reduction in the current account } \\
\text { deficit of at least } 6 \% \text { of GDP in three } \\
\text { years. Initial balance has to be a } \\
\text { deficit }\end{array}$ & $\begin{array}{l}\text { Author's elaboration based on } \\
\text { data of current account deficit } \\
\text { (World Development Indicators) }\end{array}$ \\
\hline $\begin{array}{l}\text { Current-Account } \\
\text { Reversal II }\end{array}$ & $\begin{array}{l}\text { Reduction in the current account } \\
\text { deficit of at least } 4 \% \text { of GDP in one } \\
\text { year. Initial balance has to be a deficit }\end{array}$ & $\begin{array}{l}\text { Author's elaboration based on } \\
\text { data of current account deficit } \\
\text { (World Development Indicators) }\end{array}$ \\
\hline Sudden Stop & $\begin{array}{l}\text { Reduction of net capital inflows of at } \\
\text { least 5\% of GDP in one year. The } \\
\text { country in question must have } \\
\text { received an inflow of capital larger to } \\
\text { its region's third quartile during the } \\
\text { previous two years prior to the } \\
\text { "sudden stop." }\end{array}$ & $\begin{array}{l}\text { Author's elaboration based on } \\
\text { data of financial account (World } \\
\text { Development Indicators) }\end{array}$ \\
\hline Currency Crisis A & $\begin{array}{l}\text { Dummy variable for occurrence of a } \\
\text { currency crisis: index of "external } \\
\text { pressures" exceeds its mean by } 3 \\
\text { standard deviation }\end{array}$ & $\begin{array}{l}\text { Author's elaboration based on } \\
\text { data of international reserves and } \\
\text { nominal exchange rate. }\end{array}$ \\
\hline Currency Crisis B & $\begin{array}{l}\text { Dummy variable for occurrence of a } \\
\text { currency crisis: index of "external } \\
\text { pressures" exceeds its mean by } 3 \\
\text { standard deviation exclusively by } \\
\text { changes in the nominal exchange rate }\end{array}$ & $\begin{array}{l}\text { Author's elaboration based on } \\
\text { data of nominal exchange rate. }\end{array}$ \\
\hline $\begin{array}{l}\text { Nominal exchange } \\
\text { rate }\end{array}$ & Local currency units per dollar & $\begin{array}{l}\text { International Financial Statistics, } \\
\text { IMF }\end{array}$ \\
\hline Real exchange rate & Bilateral CPI based real exchange rate & $\begin{array}{l}\text { Author's elaboration based on } \\
\text { data of nominal exchange rate } \\
\text { and CPI. (International Financial } \\
\text { Statistics, IMF) }\end{array}$ \\
\hline Terms of trade & $\begin{array}{l}\text { Change in terms of trade-exports as } \\
\text { capacity to import (constant LCU) }\end{array}$ & World Development Indicators \\
\hline Reserves to GDP & Net international reserves over GDP & World Development Indicators \\
\hline $\begin{array}{l}\text { Domestic credit } \\
\text { growth }\end{array}$ & Annual growth rate of domestic credit & World Development Indicators \\
\hline
\end{tabular}


Appendix

Description of the Data

(Continuation)

\begin{tabular}{l|l|l}
\hline Variable & Definition & Source \\
\hline $\begin{array}{l}\text { External debt to } \\
\text { GDP }\end{array}$ & Total external debt over GDP & World Development Indicators \\
Fiscal deficit to GDP & $\begin{array}{l}\text { Overall budget to GDP } \\
\text { GDP per capita in 1995 US\$ dollars }\end{array}$ & World Development Indicators \\
$\begin{array}{l}\text { GDP per capita } \\
\text { mobility }\end{array}$ & $\begin{array}{l}\text { Index: (low mobility) to 100 (high } \\
\text { mobility) }\end{array}$ & Edwards (2005) \\
Openness & $\begin{array}{l}\text { Trade openness: exports plus imports } \\
\text { over GDP }\end{array}$ & World Development Indicators \\
\hline
\end{tabular}




\section{References}

Ades, A. and F. Kaune. 1997. “A New Measure of Current Account Sustainability for Developing Countries," Goldman-Sachs Emerging Markets Economic Research.

Barro, R., Sala-I-Martin, X., 1995. Economic Growth. McGraw Hill, New York.

Benassy-Quere, A. Duran-Vigeron, P. Lahreche-Revil, A. and V. Mignon. 2004. "Burden Sharing and Exchange Rate Misalignments Within the Group of Twenty," in Bergsten, C.F. and J. Williamson (Editors): Dollar Adjustment: How Far? Against What?, Institute for International Economics, Washington D.C., November.

Bergsten, C.F. and J. Williamson. 2003. Dollar Overvaluation and the World Economy, Special Report 16, Institute for International Economics, Washington D.C., November.

2004. Dollar Adjustment: How Far? Against What?, Institute for International Economics, Washington D.C., November.

Blanchard, O., Giavazzi,F. and F. Sa. 2005. "The U.S. Current Account and the Dollar," NBER Working Paper No. 11137, February.

Caballero, R., Farhi, E., and Hammour, M. 2004. "Speculative Growth: Hints from the U.S. Economy," NBER Working Paper No. 10518, May.

Calvo, G. A., Izquierdo, A. and L. F. Mejia. 2004. "On the Empirics of Sudden Stops: The Relevance of Balance-Sheet Effects," NBER Working Paper No. 10520, May.

Choi, C-Y., Mark, N. and D. Sul. 2004. "Unbiased Estimation of the Half-Life to PPP Convergence in Panel Data," NBER Working Paper No. 10614, July. 
Cooper, R. 2004.“America's Current Account Deficit Is Not Only Sustainable, It Is Perfectly Logical Given the World's Hunger for Investment Returns and Dollar Reserves," Financial Times, November 1st.

Croke, H. , Kamin S. B. and S. Leduc. 2005. "Financial Market Developments and Economic Activity during Current Account Adjustments in Industrial Economies," International Finance Discussion Papers 827, Board of Governors of the Federal Reserve System.

Corden, W. M. 1994. Economic Policy, Exchange Rates, and the International System. Oxford: Oxford University Press, and Chicago: The University of Chicago Press.

Dollar, D., 1992. "Outward-Oriented Developing Economies Really Do Grow More Rapidly: Evidence from 95 LDCs, 1976-1985," Economic Development and Cultural Change, 40(3): 523-44.

Dooley, M., D. Folkerts-Landau and P. Garber 2004a. "The Revived Bretton Woods System: The Effects of Periphery Intervention and Reserve Management on Interest Rates \& Exchange Rates in Center Countries," NBER Working Paper No. 10332, March.

2004b. "Direct Investment, Rising Real Wages and the Absorption of Excess Labor in the Periphery," NBER Working Paper No. 10626, July.

Edwards, S. 2005. "Capital Controls, Sudden Stops and Current Account Reversals," in S. Edwards (ed): International Capital Flows, forthcoming.

2004. "Thirty Years of Current Account Imbalances, Current Account

Reversals and Sudden Stops," IMF Staff Papers, Vol. 61, Special Issue: 1-49. International Monetary Fund. 
2003. "Debt Relief and the Current Account: An Analysis of the HIPC Initiative," World Economy, 26(4): 513-31.

2002. "Does the Current Account Matter?" in Preventing Currency Crises in Emerging Markets, S. Edwards and J. A. Frankel (editors), The University of Chicago Press. 21-69.

1999. "Crisis Prevention: Lessons from Mexico and East Asia,", NBER Working Paper No. 7233, July.

1995. Crisis and Reform in Latin America: From Despair to Hope, Oxford and New York: Oxford University Press for the World Bank.

Edwards, S. and E. Levy Yeyati. 2004. "Flexible Exchange Rates as Shock Absorbers," European Economic Review, forthcoming.

Eichengreen, B., A. K. Rose and Ch. Wyplosz. (1996): "Contagious Currency Crises", NBER Working Paper No. 5681, July.

Frankel, J. A., and A. K. Rose (1996): "Currency Crashes in Emerging Markets: An Empirical Treatment," Journal of International Economics, 41(3-4): 351-366.

Frankel, J. A. and E. A. Cavallo. 2004. "Does Openness to Trade Make Countries More Vulnerable to Sudden Stops, Or Less? Using Gravity to Establish Causality,” NBER Working Paper No. 10957, December.

Freund, Caroline (2000): "Current Account Adjustments in Industrialized Countries," International Finance Discussion Papers $\mathrm{N}^{\circ}$ 692, Board of Governors of the Federal Reserve System. 
Guidotti, P., Villar, A. and F. Sturzenegger. 2003 "Aftermaths of Current Account Reversals: Exports Growth or Import Compression," Presented at the $8^{\text {th }}$ LACEA Meeting, Puebla-Mexico, October.

Gourinchas P. O. and H. Rey.2005. "International Financial Adjustment,” NBER Working Paper 11155, February.

Hopper, P., Johnson, K. and J. Marquez (2000): "Trade Elasticities for G-7 Countries," Princeton Studies in International Economics, 87, Princeton University.

Kraay, A. and J. Ventura. 2002. "Current Accounts in the Long and Short Run", NBER Working Paper 9030, June.

Lane, P. R. and G. M. Milesi-Ferretti, G. M. 2004a. "International Investment Patterns," CEPR Discussion Papers 4499. 2004b. "Financial Globalization and Exchange Rates," NBER Macroeconomics Annual, 73-115. 2001. "The External Wealth of Nations: Measures of Foreign Assets and Liabilities for Industrial and Developing Countries," Journal of International Economics, Vol. 55 (2): 263-294.

Mann, C. 2004. "The US Current Account, New Economy Services, and Implications for Sustainability," Review of International Economics, 12 (2): 262 - 276. . 2003. "How Long the Strong Dollar?,", in Bergsten, C.F. and J. Williamson (Editors): Dollar Overvaluation and the World Economy, Special Report 16, Institute for International Economics, Washington D.C., November. 

1999. Is the U.S. Trade Deficit Sustainable?. Institute for International Economics, Washington D.C., September.

Milesi-Ferretti, Gian Maria and Assaf Razin. (2000), "Current Account Reversals and Curreency Crises: Empirical Regularities" in P. Krugman (Ed), Currency Crises, U. of Chicago Press.

Mussa, M. 2004."Exchange Rate Adjustments Needed to Reduce Global Payments Imbalance," in Bergsten, C.F. and J. Williamson (Editors): Dollar Adjustment: How Far? Against What?, Institute for International Economics, Washington D.C., November.

Obstfeld, M. and K. Rogoff. 2000. "Perspectives on OECD Capital Market Integration: Implications for U.S. Current Account Adjustment," in Federal Reserve Bank of Kansas City, Global Economic Integration: Opportunities and Challenges, March, pp. 169-208.

2004. "The Unsustainable US Current Account Position Revisited," NBER Working Paper 10869, November.

O’Neill, J. and J. Hatzius. 2004. "US Balance of Payments. Unsustainable, But...," Global Economics Papers No. 104, New York: Goldman and Sachs. 2002. "US Balance of Payments: Still Unsustainable," Global Economics Paper No. 70, New York: Goldman-Sachs.

Roubini, N. and B. Setser. 2004. "The US as a Net Debtor: The Sustainability of the US External Imbalances," mimeo, Stern School of Business, August.

Sachs, J.D., Warner, A.M., 1995. "Economic Reform and the Process of Global Integration," Brookings Papers on Economic Activity (1), 1-118. 
Taylor, A. M. 2002. “A Century of Current Account Dynamics," NBER Working Paper No. 8927, May.

Tille, C.. 2003. "The Impact of Exchange Rate Movements on US Foreign Debt," Current Issues in Economics and Finance 9, pp.1-7, January.

Wren-Lewis, S. 2004. "The Needed Changes in Bilateral Exchange Rates”, in Bergsten, C.F. and J. Williamson (Editors): Dollar Adjustment: How Far? Against What?, Institute for International Economics, Washington D.C., November. 